\title{
Novel targeted therapies for Parkinson's disease
}

\author{
Theodora Ntetsika ${ }^{1,2}$, Paraskevi-Evita Papathoma ${ }^{1,3}$ and loanna Markaki ${ }^{1,2^{*}}$ (])
}

\begin{abstract}
Parkinson's disease (PD) is the second more common neurodegenerative disease with increasing incidence worldwide associated to the population ageing. Despite increasing awareness and significant research advancements, treatment options comprise dopamine repleting, symptomatic therapies that have significantly increased quality of life and life expectancy, but no therapies that halt or reverse disease progression, which remain a great, unmet goal in PD research. Large biomarker development programs are undertaken to identify disease signatures that will improve patient selection and outcome measures in clinical trials. In this review, we summarize PD-related mechanisms that can serve as targets of therapeutic interventions aiming to slow or modify disease progression, as well as previous and ongoing clinical trials in each field, and discuss future perspectives.
\end{abstract}

Keywords: Parkinson's disease, Therapeutics, Drug development

\section{Background}

Parkinson's disease (PD) is the second most common neurodegenerative disorder worldwide, affecting $2-3 \%$ of the population $\geq 65$ years of age (Pringsheim et al. 2014). Incidence estimates range from 5 to $>35$ new cases per 100,000 individuals each year (Twelves et al. 2003) and while the figures are expected to further increase with the ageing of population (Marras et al. 2018), no disease modifying therapies are yet available (Espay et al. 2018). Levodopa brought a revolution in the field of management of PD by significantly improving parkinsonian symptoms, quality of life, and normalizing life expectancy (Jankovic 2002; Tambasco et al. 2018). More recent dopaminergic therapies, including dopamine agonists, monoamine oxidase $\mathrm{B}$ inhibitors, catechol-Omethyltransferase inhibitors (Rascol et al. 2003) as well as several unique formulations of levodopa, have been developed to address levodopa therapy shortcomings (Armstrong et al. 2020). Continuous duodenal infusion

\footnotetext{
*Correspondence: ioanna.markaki@ki.se

${ }^{2}$ Center of Neurology, Academic Specialist Center, Solnavägen 1E, 113 65 Stockholm, Sweden

Full list of author information is available at the end of the article
}

of levodopa/carbidopa intestinal gel and apomorphine subcutaneous pumps are such examples (Armstrong et al. 2020). Also, deep brain stimulation (DBS) is a very useful approach for patients with motor complications not responsive to medication adjustments (Armstrong et al. 2020). All these therapies have been of great value in the management of PD symptoms, although wearing out effect of oral medications, limited therapeutical options for patients with advanced disease, and the failure of clinical trials on disease modifying agents so far, have led researchers to reconsider clinical trial design (Cedarbaum 2018). Current and future efforts in the development of PD treatments involve the development and application of biomarkers that improve and objectify measurements of target engagement, pharmacokinetics and pharmacodynamics, disease state, safety and disease outcome (Cedarbaum 2018).

With regard to PD pathophysiology, the selective neuronal death in substantia nigra pars compacta constitutes a landmark finding, followed by the description of the classical basal ganglia model comprising the direct, indirect and the more recently added, hyperdirect pathways that regulate the control of movement (Albin et al. 1989; Kish et al. 1988), as well as the most recent view of PD original author(s) and the source, provide a link to the Creative Commons licence, and indicate if changes were made. The images or other third party material in this article are included in the article's Creative Commons licence, unless indicated otherwise in a credit line to the material. If material is not included in the article's Creative Commons licence and your intended use is not permitted by statutory regulation or exceeds the permitted use, you will need to obtain permission directly from the copyright holder. To view a copy of this licence, visit http://creativecommons.org/licenses/by/4.0/. 
as a systemic disorder, with profound involvement of the peripheral and enteric nervous system (Beach et al. 2010). The original PD model was mainly developed from data collected in rodents and primates with tract-tracing invasive approaches, immunochemistry and in situ hybridization techniques (Quartarone et al. 2020), and it correlates poorly with a considerable fraction of parkinsonian symptoms. Thus, a more systemic approach is necessary to describe pathological processes in PD as a multifactorial disease with complex symptom pattern (Obeso et al. 2017). Following the Braak theory of ascending pathology from the brainstem towards the cortex, in the PD brain (Braak et al. 2003), the research focus has moved towards the network degeneration hypothesis. Multimodal neuroimaging including functional magnetic resonance tomography (MRI), blood oxygen level-dependent (BOLD) MRI, and positron emission tomography (PET) have been utilized in connectivity studies. Despite the lack of reliable a-synuclein tracers, as opposed to histopathological studies, functional neuroimaging enables longitudinal monitoring of disease mechanisms along with symptom progression, thereby providing tools that increase diagnostic accuracy (Pagano et al. 2016; Politis 2014). A disease-specific metabolic pattern based on ${ }^{18} \mathrm{~F}$-fluorodexyglucose (FDG)-PET has been developed and repeatedly validated in PD populations and has also been suggested as an objective tool of tracking treatment effect in clinical trials (Schindlbeck et al. 2018). In a recent, trimodal approach comprising ${ }^{18} \mathrm{~F}$-FDG-PET, functional MRI and ${ }^{18} \mathrm{~F}$-DOPA-PET, evidence was found for network-dependent neurodegeneration in PD by recapitulating the impact of nigrostriatal pathway impairment on putaminal dopamine depletion to striatocortical motor circuit dysfunction, thus providing a biomarker for the quantification of disease progression (Ruppert et al. 2020). In the present review, we summarize novel pharmacotherapeutic and non-pharmacological approaches with specific mention in clinical trials that apply neuroimaging and other objective disease-specific biomarkers on patient selection and treatment effect measurements.

\section{Gene therapies}

Gene therapy is a rapid evolving, genome editing technology aiming to treat a disease by genetically modifying populations of cells that are either directly functionally impaired or capable of relieving disease symptoms (Coune et al. 2012). The technology is based on the use of a vector to carry DNA, RNA, antisense oligonucleotides or DNA- or RNA-editing enzymes into specific cells to modulate gene expression (Borel et al. 2014; Haggerty et al. 2020; Han et al. 2019; Hudry et al. 2019). Increasing clinical evidence of viral vector-based gene therapy approaches is available in PD (Axelsen et al.
2018; Fiandaca et al. 2010), as a result of studies on animal models that provided proof for the safety and efficacy of two families of viral vectors, characterized by both durable gene expression in neurons and minimal immunogenicity: adeno-associated viruses (AAVs) and lentiviruses (LVs)(Wong et al. 2006; Wu et al. 2006). AAVs have been widely used as vectors in central nervous system (CNS) disorders (Cearley et al. 2007). The AAV serotype 2 (AAV2) has demonstrated excellent tropism for neurons (Cearley et al. 2007; Fiandaca et al. 2009), while other AAV serotypes have been used for targeting other cell populations in the CNS, such as astrocytes (Hanlon et al. 2019) and microglia (Rosario et al. 2016). Also, AAV2 vectors are characterized by limited risk of insertional mutagenesis for the host (Berns et al. 2017; Gao et al. 2005) and effective expression after one-time delivery treatment (Christine et al. 2019).

The AAV serotype 9 (AAV9) has the highest tropism for the CNS (Kantor et al. 2014), and it is further advanced by the use of self-complementary vectors that significantly increase the viral transduction in several tissues (McCarty 2008), including the adult motor neurons in the spinal cord, due to its unique ability to penetrate the blood brain barrier (Duque et al. 2009). Based on these properties, AAV9 was investigated in mice models of spinal muscular atrophy (SMA), a monogenic disease characterized by the degeneration of the spinal motor neurons, with positive results in motor neuron survival, reversal of the phenotype and increased survival (Dominguez et al. 2011; Foust et al. 2010; Valori et al. 2010). Subsequent studies on non-human primates (Bevan et al. 2011; Dehay et al. 2012) and one clinical trial on patients with SMA (Mendell et al. 2017) confirmed the safety and efficacy of treatment, and Zolgensma ${ }^{\rightarrow}$ was the first gene therapy to be approved in 2019 (Hoy 2019).

Lentivectors have been developed from primate lentiviruses, such as the wild-type human immunodeficiency virus type 1 and non-primate lentiviruses, such as the equine infectious anemia virus, by progressively removing most of the viral genes from the vector genome to limit the risk of producing replication-competent viral particles (Cronin et al. 2005; Dull et al. 1998; Naldini et al. 1996; Olsen 1998; Zufferey et al. 1998; Zufferey et al. 1997). Lentivectors tropism can be specifically modified through pseudotyping strategies (Naldini et al. 1996). However, LVs can increase the risk for insertional mutagenesis, due to their capacity to integrate into the host genome (Coune et al. 2012), and several strategies have been introduced to improve their safety profile, including directing integration to heterochromatin regions of the genome, introduction of selfinactivating mutations, production of non-integrating 
lentivectors and, more recently, removal of a sequence element involved in plus-strand DNA synthesis shown to further reduce integration and increase the efficiency of formation of circular episomes (Apolonia et al. 2007; Gijsbers et al. 2010; Kantor et al. 2011; Philippe et al. 2006; Zufferey et al. 1998).

Gene therapy clinical trials in PD have focused on 4 main targeted approaches: (1) restoring dopamine synthesis, (2) neuroprotection, (3) genetic neuromodulation and (4) addressing disease-specific pathogenic variants (Merola et al. 2020). Gene therapies targeting pathogenic GBA variants are addressed in the section "Glucocerebrosidase targeting therapies".

PD trials focusing on dopamine restoration strategies have targeted either aromatic L-amino acid decarboxylase (AADC) alone using AAV2 as vectors (AAV2-AADC) (Christine et al. 2019; Christine et al. 2009; Mittermeyer et al. 2012; Muramatsu et al. 2010) or a triad of key enzymes in the dopamine biosynthetic pathway including AADC, tyrosine hydroxylase $(\mathrm{TH})$ and GTP-cyclohydrolase (GCH1) using lentivectors $($ LV-GCH1-TH-AADC; ProSavin $\rightarrow$ ) (Palfi et al. 2014). AAV-AADC phase-I clinical trials demonstrated safety and a significant improvement of both motor and nonmotor symptoms as assessed by the Unified Parkinson Disease Rating Scale (UPDRS), a decrease in OFF-time duration without an increased effect of ON-time dyskinesias, as well as an increase in the uptake of the AADC tracer at PET, which was used as a measure of gene expression (Christine et al. 2009; Mittermeyer et al. 2012; Muramatsu et al. 2010). A phase-Ib study demonstrated a dose-dependent improvement of clinical outcomes, including increase in $\mathrm{ON}$-time duration without dyskinesias and quality of life, dopaminergic medications reduction, and AADC enzymatic activity assessed by PET (Christine et al. 2019). These results led to an ongoing phase-II, randomized, sham surgery controlled, double-blind, multi-center clinical trial (NCT03562494, Table 1) to primarily assess changes in ON-time duration without dyskinesias, as recorded by participants in their PD diary. As for LVGCH1-TH-AADC, results of a phase I/II trial with two study sites (France and UK) showed long-term safety and tolerability of ProSavin ${ }^{\circledR}$, as well motor symptom improvement, as assessed with the UPDRS part 3 motor score. An improved version of ProSavin ${ }^{\circledR}$, OXB-102 (NCT03720418, Table 1), is under investigation in a two-phase trial including an open-label, dose-finding phase, in which patients will receive one of three escalating doses, and a randomized, double-blind phase in which patients will be randomized to either an active group receiving the selected dose from phase 1, or a control group.
Two neurotrophic factor gene therapies delivered via AAV2 vectors have provided either neurturin (AAV2NRTN) or glial cell-line derived neurotrophic factor (AAV2-GDNF) to PD patients. GDNF is a 134 amino acid protein belonging in the GDNF family ligands and the most potent trophic factor of dopaminergic neurons (Lin et al. 1993). After years of studies in preclinical models including GDNF-transgene infusion as well as direct GDNF protein infusion intraparenchymally or intraventricularly (Gash et al. 1996; Kells et al. 2010; Pascual et al. 2011; Richardson et al. 2011; Tomac et al. 1995), several clinical trials have been developed to investigate the efficacy of GDNF treatment in the management of PD. In a phase 1 safety trial, GDNF delivered directly into patients' putamen (Fig. 1) showed no serious clinical side effects, improvement of UPDRS part 2 and 3 scores, reduction of dyskinesias and significant increase in putamen dopamine storage assessed by PET (Gill et al. 2003). An escalation, dose-ranging trial using MRI monitored AAV2-GDNF putamen infusion showed good safety and tolerability of the therapy, substantial stability of the UPDRS scores up to 18 months post treatment and an increase in ${ }^{18} \mathrm{~F}$-DOPA uptake 6 to 18 months post treatment, suggesting a neurotrophic effect on dopaminergic neurons (Heiss et al. 2019). GDNF administration using intermittent intraputaminal convection-enhanced delivery via a skull-mounted transcutaneous port showed less promising results (Whone et al. 2019). However, the patients that responded with an improvement of motor outcome as assessed by UPDRS part 3 continued to experience clinical improvement in an open-label extension study (Whone et al. 2019). An ongoing phase Ib trial (NCT04167540) is designed to evaluate the safety and potential clinical effect of MRI-guided intraputaminal delivery of AAV2-GDNF in two cohorts of patients with either early-stage or advanced PD, thus contributing with important knowledge on the therapeutic effect early in PD course.

Cerebral dopamine neurotrophic factor (CDNF) is an additional protein, 161 amino acids long, with structurally and functionally distinct properties compared to other neurotrophic factors (Lindahl et al. 2017), including the regulation of apoptosis and unfolded protein response, and reduction of glial cell secretion of proinflammatory cytokines. CDNF targets preferably injured cells and diffuses broadly within the tissues - a property that may result in benefits beyond the nigrostriatal pathway and motor symptom alleviation. A phase 1 clinical trial aiming to investigate the safety and tolerability of intraputaminal infusion of CDNF in patients with advanced PD and motor fluctuations (NCT03295786, NCT03775538) is recently completed and a long-term follow-up, safety study (NCT04228653) is ongoing until 
Table 1 Current non-pharmaceutical disease-modifying ongoing clinical trials

\begin{tabular}{|c|c|c|c|c|c|c|c|}
\hline Mechanism & Intervention & $\begin{array}{l}\text { ClinTrial } \\
\text { Indentifier }\end{array}$ & Phase & $\begin{array}{l}\text { Target } \\
\text { population }\end{array}$ & Primary outcome & $\begin{array}{l}\text { Other secondary } \\
\text { outcomes } \\
\text { of interest }\end{array}$ & Sponsor \\
\hline \multirow[t]{2}{*}{ Gene therapies } & $\begin{array}{l}\text { Vector genome: } \\
\text { VY-AADC02 }\end{array}$ & NCT03562494 & $\|$ & $\begin{array}{l}\text { Moderate to } \\
\text { Advanced PD } \\
\text { with motor } \\
\text { Fluctuations }\end{array}$ & $\begin{array}{l}\text { Changes in ON } \\
\text { time without } \\
\text { troublesome } \\
\text { dyskinesia }\end{array}$ & . & $\begin{array}{l}\text { Neurocrine Bio- } \\
\text { sciences }\end{array}$ \\
\hline & $\begin{array}{l}\text { Lentiviral vector: } \\
\text { OXB-102 }\end{array}$ & NCT03720418 & $|/| \mid$ & Bilateral PD & $\begin{array}{l}A E, S A E, \text { Changes } \\
\text { in MRI }\end{array}$ & & Sio Gene Therapies \\
\hline Neuromodulation & MRgFUS & $\begin{array}{l}\text { NCT04002596 } \\
\text { NCT03319485 } \\
\text { NCT02263885 } \\
\text { NCT02246374 } \\
\text { NCT03608553 }\end{array}$ & NA & Advanced PD & $\begin{array}{l}\text { AE, } \\
\text { Responders, } \\
\text { Changes in CRST, } \\
\text { Changes in MDS- } \\
\text { UPDRS }\end{array}$ & & InSightec \\
\hline \multirow[t]{6}{*}{ Neuromodulation } & rTMS & NCT04238000 & NA & PD & Motor Outcomes & & $\begin{array}{l}\text { Fondazione Euro- } \\
\text { pea di Ricerca } \\
\text { Biomedica Ferb } \\
\text { Onlus }\end{array}$ \\
\hline & & NCT04431570 & NA & $\begin{array}{l}\text { PD, freezing of } \\
\text { gait }\end{array}$ & Changes in FOGT & fMRI & $\begin{array}{l}\text { Peking Union } \\
\text { Medical College } \\
\text { Hospital }\end{array}$ \\
\hline & & NCT04116216 & $\|$ & PD & $\begin{array}{l}\text { Changes in MDS- } \\
\text { UPDRS part III }\end{array}$ & . & $\begin{array}{l}\text { Universidade } \\
\text { Federal de } \\
\text { Pernambuco }\end{array}$ \\
\hline & & NCT03836950 & |/II & PD & $\begin{array}{l}\text { Changes in Cogni- } \\
\text { tive Outcomes }\end{array}$ & & $\begin{array}{l}\text { VA Office of } \\
\text { Research and } \\
\text { Development }\end{array}$ \\
\hline & & NCT02346708 & NA & PD with $\mathrm{MCl}$ & $\begin{array}{l}\text { Changes in } \\
\text { magnetoen- } \\
\text { cephalography } \\
\text { connectivity } \\
\text { measures }\end{array}$ & & $\begin{array}{l}\text { University of Colo- } \\
\text { rado, Denver }\end{array}$ \\
\hline & & NCT03552861 & NA & $\begin{array}{l}\text { PD with Depres- } \\
\text { sion or Cogni- } \\
\text { tive Impairment }\end{array}$ & $\begin{array}{l}\text { Changes in HAMD } \\
\text { and BDI }\end{array}$ & . & $\begin{array}{l}\text { Guangdong Pro- } \\
\text { vincial People's } \\
\text { Hospital }\end{array}$ \\
\hline
\end{tabular}

AE Adverse Events, BDI Beck Depression Inventory, CRST Clinical Rating Scale for Tremor, $f M R I$ functional Magnetic Resonance Imaging, FOGT Freezing Of Gait Questionnaire, HAMD Hamilton Depression Scale, MCI Mild Cognitive Impairment, MDS-UPDRS MDS-Unified Parkinson's Disease Rating Scale, MRgFUS Magnetic Resonance Guided Focused Ultrasound, MRI Magnetic Resonance Imaging, NA Not Applicable; rTMS Repetitive Transcranial Magnetic Stimulation, PD Parkinson's Disease

March 2023. CDNF is delivered intracerebrally with an implanted drug delivery system, thereby not being a gene therapy, yet included in this section of the Review, along with other neurotrophic factors.

Neurturin, a structurally $42 \%$ similar to GDNF neurotrophic factor expressed in the substantia nigra and striatum (Kotzbauer et al. 1996), has been another target for AAV2 mediated gene therapy (CERE-120). A phase I dose-escalating, open-label study designed to assess the safety, tolerability and biologic activity of CERE-120 revealed no clinically significant side effects and improvement of UPDRS motor score both in ON and OFF-medication state, without troublesome dyskinesias one-year after treatment (Marks et al. 2008). However, a subsequent multi-center, double-blind, sham-surgery controlled trial showed no superiority of CERE-120 treatment to sham surgery, as assessed with the UPDRS motor score, during equally long follow-up period. Extended follow-up over 15 to 24 months also failed to demonstrate significant clinical improvement in CERE-120 group compared to the control group (Warren Olanow et al. 2015).

In order to restore inhibitory control of the subthalamic nucleus (STN) in patients with PD (Jahanshahi et al. 2015), gene therapy using AAV vectors to deliver glutamate decarboxylase (GAD) into the STN has been introduced (Fig. 1). GAD, the enzyme that catalyzes the formation of the inhibitory neurotransmitter gammaaminobutyric acid (GABA), has two forms GAD65 and GAD67, expressed by two different genes (Erlander et al. 1991). The expression and activity of GADs is directly connected to GABA levels and subsequent GABAergic neurotransmission at the inhibitory synapse (Lee et al. 2019). An open label, phase I trial showed safety and tolerability of unilateral, subthalamic AAV-GAD injection, as well as significant improvements in the UPDRS motor 


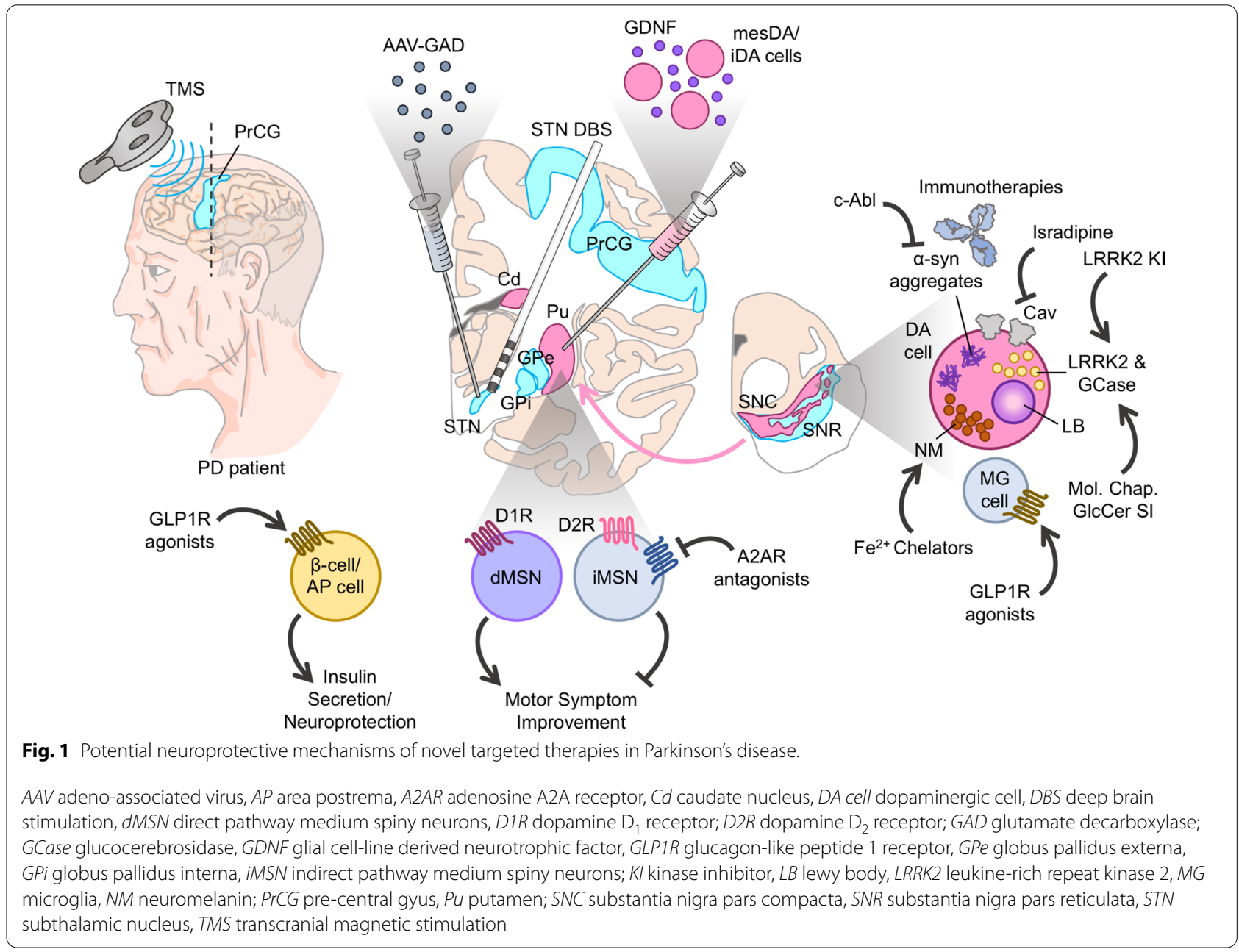

score, predominantly on the side of the body that was contralateral to surgery up to 12 months after treatment (Kaplitt et al. 2007). These results prompted a phase-II, double-blind, sham-surgery controlled, randomized trial which showed a significantly greater improvement of the UPDRS sub-scores in the AAV-GAD group compared to the sham group, over a 6-month follow-up period (LeWitt et al. 2011). Long-term follow-up confirmed persistent clinical benefit, and good safety and tolerability outcome 12 months post treatment (Niethammer et al. 2017). FDG-PET scans performed preoperatively and at 6 and 12 months after surgery revealed the development of a unique, treatment-dependent, polysynaptic brain circuit linking the STN to motor cortical regions, which correlated with clinical improvement in the AAV2-GAD treated patients (Niethammer et al. 2018).

Thus, in clinical trials of gene therapies, outcome measures comprise both clinical improvement and functional neuroimaging markers of pharmacodynamics (e.g. dopaminergic neuron density and AADC activity). Also, in an attempt to closer explore drug effect on brain connectivity, consecutive FDG-PET scans were successfully combined with network analysis to provide insight in the metabolic signature of gene therapy, suggesting a new tool for the evaluation of therapeutic efficacy in PD.

\section{Targeting alpha-synuclein}

Alpha-synuclein ( $\alpha$-syn) is a 140 -amino-acid protein encoded by the SNCA gene, that is abundant in the brain, and more specifically at the neuronal presynaptic terminals. Its function is not fully understood, but it seems to have a role in synaptic vesicle recycling and neurotransmitter release (Sulzer et al. 2019). Aggregation of $\alpha$-syn and accumulation in cytoplasmic inclusions known as Lewy bodies, is the pathological hallmark of PD (Spillantini et al. 1997). Although the precise mechanism of toxicity is still to be revealed, current disease-modifying therapies focus on targeting the spread, production, aggregation, and degradation of $\alpha$-syn. 


\section{Decreasing the expression of a-synuclein}

Manipulation of $\alpha$-syn levels by gene silencing with RNA interference has been shown to be beneficial in normalizing $\alpha$-syn expression and improve motor function in experimental studies (McCormack et al. 2010; Takahashi et al. 2015), yet fine-tuned balance is necessary to avoid nigrostriatal neurotoxicity caused by excess downregulation (Gorbatyuk et al. 2010). DNA methylation at SNCA intron 1 is a regulator of the $\alpha$-syn transcription, and methylation levels differ in PD compared to controls (Jowaed et al. 2010), thus providing a target for tight control of $\alpha$-syn expression levels. Novel clustered regularly interspaced short palindromic repeats technology has been successfully used in fine tuning the downregulation of SNCA expression in stem cell-derived dopaminergic neurons, suggesting a new approach (Kantor et al. 2018).

\section{Prevention of a-syn aggregation}

High-throughput screening of compound libraries in combination with medicinal chemistry optimization have recently led to the development of the novel oligomer modulator anle138b, which showed to inhibit the formation of pathological oligomers in-vitro, as well as in several mouse models of prion and PD (Wagner et al. 2013). The first in human clinical trial on healthy volunteers was completed in august 2020 (NCT04208152), and reported no side effects in doses up to $300 \mathrm{mg}$. Also, plasma levels exceeded those required for efficacy in animal models, and the uptake was not affected by food. Based on these results, further funding was secured for testing in PD patients.

Heat shock proteins (HSPs) are small molecular chaperones that serve in protein homeostasis and prevent protein aggregation and toxicity in conditions of cellular stress. Several HSPs have been observed as components of Lewy body inclusions, and manipulation of their expression in in-vitro and in-vivo models has been shown to modulate $\alpha$-syn aggregation and toxicity (Sinnige et al. 2020), alluding that restoration of physiological proteostasis could serve as a therapeutic target in neurodegenerative diseases. Several other small molecules have been investigated in pre-clinical studies for their efficacy in preventing $\alpha$-syn aggregation. Leuco-methylthioninium bis (hydromethanesulfonate) is one such compound that has been reported to prevent tau aggregation and has subsequently been tested in cell lines and a transgenic mouse model of PD with encouraging results (Schwab et al. 2017). NPT-100-18A is a de novo compound developed by Wrasidlo and colleagues through molecular methods that targeted the $\mathrm{C}$-terminal of $\alpha$-syn, which has an important role in dimerization and membrane penetration (Wrasidlo et al. 2016). As a cyclic peptidomimetic compound, NPT-100-18A interferes at the sites of $\alpha$-syn monomer interaction, thus preventing oligomerization and toxicity. The results in in-vitro studies and in two different transgenic rodent models showed decreased a-syn aggregation, reduced cortical synaptic accumulation and normalization of inflammatory and neuronal markers (Wrasidlo et al. 2016). The molecular tweezer CLR01 inhibits $\alpha$-syn aggregation through binding to lysine residues of $\alpha$-syn that are crucial for its oligomerization, and it has shown efficacy, in terms of motor symptom improvement and decreased oligomeric $\alpha$-syn burden, in transgenic mouse models of PD (Bengoa-Vergniory et al. 2020).

Nilotinib is a tyrosine kinase c-Abl inhibitor approved for the treatment of leukemia, that has also shown to increase autophagy and degradation of intracellular $\alpha$-syn aggregates (Fig. 1). Phase 2 clinical trials in PD have recently concluded contradicting results regarding CNS bioavailability and alteration of dopamine metabolites, although the drug was safe and well tolerated in both studies (Simuni et al. 2020; Pagan et al. 2020). Critique has been addressed on the interpretation of the results of the published study (Pagan et al. 2020) regarding safety that has been questioned, as increasing frequency of serious adverse events was observed with increasing dose of nilotinib, and also regarding the effect of treatment on altering relevant biomarkers, as those were only measured at the end of treatment, with no baseline reference (Espay et al. 2020). Also, although the study was not an efficacy trial, it was concerning that patients in the nilotinob high-dose group showed deterioration in the activities of daily living, and the "Time Up and Go" motor test, as well as in the Montreal Cognitive Assessment score, at the end of treatment compared to baseline. Thus, a closer reflection on patient selection of potential responders, and on outcome measures that will reflect the targeted mechanism was suggested. Yet, another phase II clinical trial focusing on c-Abl inhibition (NCT03655236, Table 2) is ongoing, evaluating both clinical outcome and imaging-based biomarkers.

\section{Immunotherapies targeting a-syn}

Active immunization approaches encompass efforts to develop vaccines targeting the $\mathrm{N}$ or C-terminal of $\alpha$-syn or its aggregation forms. Early clinical trials (NCT01568099, NCT01885494, NCT02216188, NCT02618941, NCT02267434) of the $\alpha$-syn mimicking peptides PD01A (Volc et al. 2020) and PD03A in PD patients and healthy controls have shown good safety and tolerability, as well as sustainable immunogenicity over time, and phase 2 trials are under way to test clinical efficacy.

Passive immunization is based on the hypothesis that chronic intravenous administration of antibodies will halt 
Table 2 Current pharmaceutical disease-modifying clinical trials phase II and III

\begin{tabular}{|c|c|c|c|c|c|c|c|}
\hline $\begin{array}{l}\text { Targeting } \\
\text { mechanism }\end{array}$ & $\begin{array}{l}\text { ClinTrial } \\
\text { indentifier }\end{array}$ & Drug & Phase & Target population & Primary outcome & $\begin{array}{l}\text { Other secondary } \\
\text { outcomes } \\
\text { of interest }\end{array}$ & Sponsor \\
\hline \multirow[t]{2}{*}{$\begin{array}{r}\text { A2A receptor } \\
\text { antagonists }\end{array}$} & NCT03703570 & KW-6356 & $\|$ & PD & $\begin{array}{l}\text { Changes in MDS- } \\
\text { UPDRS part III }\end{array}$ & $\cdot$ & Kyowa Kirin Co., Ltd. \\
\hline & NCT02939391 & KW-6356 & $\|$ & Early PD & $\begin{array}{l}\text { Changes in MDS- } \\
\text { UPDRS part III }\end{array}$ & . & Kyowa Kirin Co., Ltd. \\
\hline $\begin{array}{l}\text { Calcium Targeting } \\
\text { Therapies }\end{array}$ & NCT02168842 & Isradipine & III & Early PD & $\begin{array}{l}\text { Changes in MDS } \\
\text { UPDRS Part I-III }\end{array}$ & . & $\begin{array}{l}\text { University of Roch- } \\
\text { ester }\end{array}$ \\
\hline \multirow{7}{*}{$\begin{array}{l}\text { Glucagon-like } \\
\text { peptide } 1 \text { recep- } \\
\text { tor agonists and } \\
\text { other antidiabetic } \\
\text { agents }\end{array}$} & NCT03659682 & Semaglutide & ॥ & Early PD & $\begin{array}{l}\text { Changes in MDS- } \\
\text { UPDRS part } 3 \text { in } \\
\text { OFF medication } \\
\text { state }\end{array}$ & . & $\begin{array}{l}\text { Oslo University } \\
\text { Hospital }\end{array}$ \\
\hline & NCT02953665 & Liraglutide & $\|$ & Early PD & $\begin{array}{l}\text { Motor Function, } \\
\text { Non-Motor Func- } \\
\text { tion, Cognitive } \\
\text { Function }\end{array}$ & & $\begin{array}{l}\text { Cedars-Sinai Medical } \\
\text { Center }\end{array}$ \\
\hline & NCT03439943 & Lixisenatide & $\|$ & Early PD & $\begin{array}{l}\text { Changes in MDS- } \\
\text { UPDRS Part III in } \\
\text { ON status }\end{array}$ & . & $\begin{array}{l}\text { University Hospital, } \\
\text { Toulouse }\end{array}$ \\
\hline & NCT04305002 & Exenatide & $\|$ & Early PD & $\begin{array}{l}\text { Changes in FDG- } \\
\text { PET network } \\
\text { analysis }\end{array}$ & $\begin{array}{l}\text { Changes in MDS- } \\
\text { UPDRS Part III } \\
\text { in ON and OFF } \\
\text { status }\end{array}$ & $\begin{array}{l}\text { Center for Neurology, } \\
\text { Stockholm } \\
\text { Karolinska Institutet }\end{array}$ \\
\hline & NCT04154072 & NLY01 & II & $\begin{array}{l}\text { Early Treatment } \\
\text { Naïve PD }\end{array}$ & $\begin{array}{l}\text { Changes in MDS } \\
\text { UPDRS Part II-III }\end{array}$ & & Neuraly, Inc \\
\hline & NCT04232969 & Exenatide & III & PD & $\begin{array}{l}\text { Changes in MDS- } \\
\text { UPDRS part III in } \\
\text { OFF medication } \\
\text { state }\end{array}$ & . & $\begin{array}{l}\text { University College, } \\
\text { London }\end{array}$ \\
\hline & NCT04269642 & Exenatide & $\|$ & Early PD & $\begin{array}{l}\text { Changes in MDS- } \\
\text { UPDRS part III } \\
\text { score }\end{array}$ & $\begin{array}{l}\text { Changes in SNBR } \\
\text { confirmed by PET } \\
\text { scan }\end{array}$ & Peptron, Inc. \\
\hline \multirow[t]{3}{*}{$\begin{array}{l}\text { Glucocerebrosi- } \\
\text { dase targeting } \\
\text { therapies }\end{array}$} & NCT02914366 & Ambroxol & $\|$ & PD Dementia & $\begin{array}{l}\text { Changes in ADAS- } \\
\text { cog and } \\
\text { ADCS-CGIC scales }\end{array}$ & $\begin{array}{l}\text { Changes in MRI } \\
\text { biomarkers }\end{array}$ & $\begin{array}{l}\text { Lawson Health } \\
\text { Research Institute }\end{array}$ \\
\hline & NCT02906020 & GZ/SAR402671 & $\|$ & $\begin{array}{l}\text { Patients with Early } \\
\text { PD Carrying a } \\
\text { GBA Gene Muta- } \\
\text { tion }\end{array}$ & $\begin{array}{l}\text { Number of Patients } \\
\text { with AE, Changes } \\
\text { in UPDRS Part II } \\
\text { and III during OFF } \\
\text { state }\end{array}$ & & $\begin{array}{l}\text { Genzyme, a Sanofi } \\
\text { Company }\end{array}$ \\
\hline & NCT04127578 & PR001A & $|/| \mid$ & $\begin{array}{l}\text { Patients with PD } \\
\text { With at Least One } \\
\text { GBA1 Mutation }\end{array}$ & $\begin{array}{l}\text { Number of TEAEs } \\
\text { and SAES }\end{array}$ & . & Prevail Therapeutics \\
\hline \multirow{2}{*}{$\begin{array}{l}\text { Targeting } \\
\text { a-synuclein: } \\
\text { Immunotherapies }\end{array}$} & NCT03100149 & $\begin{array}{l}\text { RO7046015/ } \\
\text { PRX002 }\end{array}$ & $\|$ & Early PD & $\begin{array}{l}\text { Changes in MDS- } \\
\text { UPDRS total score }\end{array}$ & $\begin{array}{l}\text { Changes in DaT- } \\
\text { SPECT }\end{array}$ & Hoffmann-La Roche \\
\hline & NCT03318523 & BlIB054 & ॥ & PD & $\begin{array}{l}\text { Changes in MDS- } \\
\text { UPDRS total score }\end{array}$ & $\begin{array}{l}\text { Change in SBR } \\
\text { measured by } \\
\text { SPECT/DATSCAN }\end{array}$ & Biogen \\
\hline $\begin{array}{l}\text { Targeting } \\
\text { a-synuclein: } \\
\text { prevention of } \\
\text { aggregation }\end{array}$ & NCT03655236 & K0706 & $\|$ & Early PD & $\begin{array}{l}\text { Changes in MDS } \\
\text { UPDRS Part II-III }\end{array}$ & $\begin{array}{l}\text { Changes in DaT- } \\
\text { SPECT }\end{array}$ & $\begin{array}{l}\text { Sun Pharma } \\
\text { Advanced Research } \\
\text { Company Limited }\end{array}$ \\
\hline $\begin{array}{l}\text { Iron Targeting } \\
\text { Therapies }\end{array}$ & NCT02655315 & Deferiprone & $\|$ & Treatment Naive PD & $\begin{array}{l}\text { Changes in total } \\
\text { MDS-UPDRS }\end{array}$ & . & $\begin{array}{l}\text { University Hospital, } \\
\text { Lille European Com- } \\
\text { mission ApoPharma }\end{array}$ \\
\hline
\end{tabular}

ADAS-cog Alzheimer's Disease Assessment Scale-cognitive subscale, ADCS-CGIS ADCS-Clinician's Global Impression of Change, AE Adverse Events, DATSCAN Dopamine Transporter With loflupane 1123, FDG-PET Positron emission tomography with 2-deoxy-2-[fluorine-18]fluoro- D-glucose, MDS-UPDRS Unified Parkinson's Disease Rating Scale, MRI Magnetic Resonance Imaging, PD Parkinson's Disease, PET positron emission tomography, SAEs Serious Adverse Events, SNBR specific to non-specific binding ratio, SBR Striatal Binding Ratio, SPECT Single Photon Emission Computed Tomography, TEAEs Treatment-Emergent Adverse Event 
the formation and spreading of pathogenic $\alpha$-syn aggregates, and potentially modify the disease course. One phase 1 study has been completed (Jankovic et al. 2018) and several are ongoing (NCT03716570, NCT03272165, NCT03611569, NCT04127695); however, a major issue has been that only $0.1-0.2 \%$ of the antibodies reach the CNS (Pardridge 2019), and that they act against the extracellular spreading but are unable to penetrate the cells (Gaston et al. 2019). Finally, it remains unclear which molecular species of $\alpha$-syn is responsible for PD pathology and how (or if) it differs from those that cause other synucleinopathies. Phase 2 trials have included striatal binding of dopamine transporter in the secondary outcome measures (NCT03100149, NCT03318523, Table 2), which would be of interest to correlate with the clinical outcome measures, and the biofluid-measured alterations to improve understanding of the drug action mechanism. Preliminary results of the first part of the PASADENA study (NCT03100149) showed that it did not meet the primary objective (i.e. improvement of MDS-UPDRS total score by $37.5 \%$ at 52 weeks), but patients in the prasinezumab group had significantly slower motor and non-motor symptom progression and improvement in imaging biomarkers consistent with disease modifying effect (Prothena Corporation 2020). Final results from the second part of the study, where the placebo arm will be re-randomized to one of the two prasinezumab doses and continue for another 52 weeks, will be of great interest and shed more light on the efficacy, mechanism of action and safety profile of the treatment.

\section{Glucocerebrosidase targeting therapies}

Glucocerebrosidase (GCase) is a 497 amino-acid lysosomal hydroxylase, which degrades glucocerebroside into ceramide and glucose (Boer et al. 2020). Individuals that are homogenous for pathogenic variants of GBA, the gene encoding GCase, develop Gaucher's disease due to excessive storage of glucocerebroside in the liver, spleen, bone, and bone marrow (Beutler 2001). Individuals who are heterozygous for GBA pathogenic variants though have an increased risk of parkinsonism and dementia (Tayebi et al. 2003), while GBA pathogenic variants are the most common known genetic cause of PD (Gan-Or et al. 2018). Also, patients with PD carrying GBA pathogenic variants have earlier age of disease onset, more rapid progression and reduced survival compared to patients without GBA pathogenic variants (Brockmann et al. 2015). GCase deficiency leads to accumulation of glucocerebroside in neurons that successively provokes formulation of toxic oligomers and decline in lysosomal proteolysis that preferentially affects $\alpha$-syn. Conversely, elevated $\alpha$-syn inhibits intracellular trafficking and lysosomal function of normal GCase in neurons, indicating the presence of a bidirectional pathologic loop between GCase and $\alpha$-syn in PD and other synucleinopathies (Aflaki et al. 2017; Choi et al. 2011; Mazzulli et al. 2011; Sardi et al. 2015). Supported by these findings, many therapeutical strategies focusing on GCase have been introduced in recent years.

Small molecular chaperones that are able to cross the blood-brain barrier and increase the activity of lysosomal GCase in neurons has been one of these novel strategies (Fig. 1). These chaperones can bind to the pathologic enzyme in the endoplasmic reticulum (ER) enabling it to fulfill quality control requirements for lysosomal trafficking. Consequently, trafficking of the enzyme to the lysosome can decrease ER-associated degradation and increase lysosomal function (Bendikov-Bar et al. 2013; Lieberman et al. 2009). Treatment with the molecular chaperone ambroxol hydrochloride was found to improve lysosomal activity in fibroblast lines generated from skin biopsies of PD patients (McNeill et al. 2014), which led to an open label uncontrolled clinical trial. Eighteen patients with moderate PD received treatment with ambroxol for 186 days, which resulted in a significant increase in their CSF $\alpha$-syn and GCase concentration levels as well as a significant decrease in UPDRS motor score, while safety and tolerability of the treatment was confirmed (Mullin et al. 2020). An ongoing, placebo-controlled, clinical trial is going to examine whether ambroxol therapy is associated with improvement of cognitive and motor symptoms of PD dementia (NCT02914366, Table 2). LTI291 is another small-molecular activator of GCase (Alzforum 2020) currently being tested in GBA-associated PD (NTR6598, NTR6705, NTR6960, NTR7299). AT3375 is a next-generation GBA chaperone that has been suggested as a potential treatment both in Gaucher's and PD (Khanna 2012).

Glucosylceramide synthase inhibitors have been shown to reduce the levels of glucosylceramide and glucosylsphingosine in the central nervous system, decelerate the accumulation of $\alpha$-syn, ubiquitin and tau proteins and improve cognitive and behavioral outcome in a GBAassociated PD mouse model (Sardi et al. 2017). Subsequently, MOVES-PD global study was undertaken in order to assess safety, tolerability and efficacy of venglustat, a brain-penetrant allosteric glucosylceramide synthase inhibitor known also as GZ/SAR402671. So far, 270 participants, i.e. GBA mutation carriers with $\mathrm{PD}$, are recruited and the study is estimated to be completed in 2024 (NCT02906020, Table 2).

GBA has also been one of the targets in AAV-mediated gene therapies. Preclinical models have shown the efficacy of AAV5-GBA and AAV9-GBA in preventing dopamine neuron loss (Rocha et al. 2015) and counteracting the widespread accumulation of $\alpha$-syn deposits 
throughout the forebrain of transgenic mouse models (Morabito et al. 2017). Based on these data, an ongoing phase $1 / 2 \mathrm{a}$, multicenter, open-label, ascending dose, first in-human clinical trial is planned to evaluate the safety of intracisternal PR001A (AAV9-GBA1) administration in patients with moderate to severe PD with at least one GBA pathogenic variant (NCT04127578, Table 2).

\section{LRRK2 targeting therapies}

Leukine-rich repeat kinase 2 (LRRK2) is a member of the Ras-of-complex (ROC) protein family (West 2017). Pathogenic variants of LRRK2 gene are an important, relatively common cause of autosomal dominant PD (Funayama et al. 2002; Paisán-Ruíz et al. 2004; Zimprich et al. 2004), especially in particular ethnic groups (Kett et al. 2012). They are also observed in patients with sporadic PD, typically manifesting as late-onset PD closely resembling idiopathic PD in terms of clinical features and response to levodopa (Tolosa et al. 2020). The Gly2019Ser, the most common among LRRK2 pathogenic variants, localizing in the kinase domain of the protein, accounts for $4 \%$ of familial and $1 \%$ of sporadic PD worldwide (Tolosa et al. 2020). Genetic and biochemical data have shown that LRRK2 pathogenic variants - particularly Gly2019Ser and variants in the GTPase Roc and COR domains of the protein - cause a toxic, gain-offunction-mechanism mediated hyperactivity of LRRK2 kinase (Chan et al. 2017; Chen et al. 2018; Cookson 2017; Cresto et al. 2019; Healy et al. 2008; West 2017). Supported by these data, novel therapeutic approaches for LRRK2-associated PD, as well as idiopathic PD, have focused on the development and use of LRRK2 kinase inhibitors (Fig. 1).

After successful inhibition of LRRK2 activity by small molecular inhibitors that resulted in decelerated $\alpha$-syn aggregation and neurodegeneration in animal models (Daher et al. 2015; Daher et al. 2014), two LRRK2 kinase inhibitors known as DNL201 and DNL151 have been introduced for administration to both healthy volunteers and patients with PD in clinical trials. Safety, tolerability and target engagement of DNL201 has already been established in a phase I, randomized, double-blind, placebo-controlled study in healthy volunteers (Tolosa et al. 2020), as well as in a placebo-controlled, dose-ranging study in 29 PD patients, including subgroups with and without LRRK2 mutation (NCT03710707), according to a press release (Therapeutics 2020). Both doses administered in PD patients were followed by more than $50 \%$ inhibition of LRRK2 and Rab10 phosphorylation in blood, and reduced bis (monoacylglycerol) phosphate in urine, which served as biomarkers of pharmacodynamic measures, and the lower dose was better tolerated. Two ongoing phase I, randomized, double-blind, placebo-controlled trials are ongoing and aim to evaluate safety, tolerability and target engagement of DNL151 in healthy volunteers (NCT04557800) and PD patients (NCT04056689). Other LRRK2 kinase inhibitors that under active development in preclinical models include MLi-2 and PF-06685360 (West 2017).

Another strategy for downregulating LRRK2 activity is the use of anti-sense oligonucleotides (ASOs) to decrease LRRK2 expression levels. This approach carries the advantage of CNS-selective LRRK2 blocking via intraventricular injection of the therapy, avoiding adverse effects of peripheral LRRK2 loss such as alterations in the kidney and lung that have been observed in LRRK2 knockout mice (Herzig et al. 2011). LRRK2-targeted ASOs injected intraventricularly in Gly2019ser mice resulted in decreased $\alpha$-syn inclusions and loss of nigral dopaminergic neurons, which also had an ameliorating effect on motor deficit (Zhao et al. 2017). Based on these data, a phase I, randomized, triple-blind, placebo-controlled ongoing trial (NCT03976349) will evaluate the safety and tolerability of an intrathecal administration of BIIB094 in patients with PD. As a secondary objective, the study will evaluate the pharmacokinetic profile of BIIB094. The study will include both patients with and without verified presence of pathogenic or likely-pathogenic LRRK2 variants.

Overall, genetic factors associated with PD are distinctly specified and well-studied regarding their function in health and disease, thereby providing more objective tools for patient selection and pharmacodynamic measurements.

\section{Glucagon-like peptide 1 receptor agonists and other antidiabetic agents}

Biological processes involved in PD share common features with obesity and type 2 diabetes mellitus (T2DM), including the dysregulation of insulin signaling in the brain. The term "brain insulin resistance" has been suggested to describe decreased sensitivity of CNS pathways to insulin, followed by disturbances in synaptic, metabolic and immune response functions (Hoyer 1998). Strategies to normalize insulin sensitivity in neurons have thus been in the spotlight of clinical trials aiming to establish whether they may provide neuroprotective actions.

Glucagon-like peptide-1 (GLP-1) is an endogenous incretin with very short circulating half-life of 1-2 minutes, produced in the enteroendocrine cells of the small intestine (Baggio et al. 2007). GLP-1 receptor agonists (GLP-1 RAs) are agents licensed for the treatment of T2DM. They function through GLP-1 receptor activation, that leads to pancreatic beta-cell proliferation, glucose-dependent insulin secretion, inhibition of glucagon 
secretion and slowing of gastric emptying (Lovshin et al. 2009). GLP-1 receptors are also found in the brainstem and hypothalamus, and their stimulation is responsible for early satiety (Alvarez et al. 2005). Apart from its glucose lowering effect, GLP-1 receptor stimulation has been investigated in animal models of PD and shown to increase neurogenesis (Bertilsson et al. 2008), to arrest and possible reverse nigrostriatal damage (Harkavyi et al. 2008), and to protect dopaminergic neurons from neurodegeneration ( $\mathrm{Li}$ et al. 2009). Different mechanisms have been suggested to mediate neuroprotection (Fig. 1 ), including inhibition of microglia activation and matrix metalloproteinase-3 expression (Kim et al. 2009), stimulation of neurogenesis (Bertilsson et al. 2008), and of mitochondrial biogenesis (Fan et al. 2010), and decreased monomeric $\alpha$-syn load in the striatum (Bassil et al. 2017). In a phase 2 study of the GLP-1 RA exenatide for 12 months in 60 PD patients, the treatment showed efficacy in motor symptoms, and a good safety profile (Athauda et al. 2017). Additional phase 2 trials (Table 2) with semaglutide (NCT03659682), liraglutide (NCT02953665) and lixisenatide (NCT03439943) evaluating treatment effect on motor symptom progression, as well as with exenatide evaluating MRI-based (NCT03456687, Table 2), and FDG-PET based (NCT04305002, Table 2) imaging markers of disease progression are ongoing, as well as a phase 3 trial of exenatide with 200 participants (NCT04232969, Table 2). Also, a phase 2 trial that aims to evaluate the effect of sustained-release formulation of exenatide in symptom improvement in $\mathrm{PD}$, is under way (NCT04269642, Table 2), as well as a dose-ranging trial on the efficacy of pegylated form of exenatide in PD-related motor symptom progression (NCT04154072, Table 2).

The neuroprotective effect of GLP-1 RAs is assumed to be mediated by improved brain insulin sensitivity (Markaki et al. 2020); however, human studies evaluating their biological effect in the CNS are limited. Functional MRI imaging studies have primarily focused on investigating brain networks involved in the anorectic effect of GLP-1 RAs (De Silva et al. 2011; Schlogl et al. 2013), but sparse mechanistic data are available for understanding neuroprotective effects of these drugs. In a more recent trial of exenatide in PD, disease modifying effects measured by nigrostriatal dopamine transporter imaging (DaTscan) were reported (Athauda et al. 2017). Subsequently, brain insulin and Akt signaling pathways were also evaluated in neuronal-derived exosomes and it was shown that exenatide treatment, but not placebo, activated these pathways (Athauda et al. 2019). This significant, secondary analysis of the trial increases understanding of the molecular mechanism underlying the treatment effect and provides a possible biomarker to measure target engagement.

\section{Calcium targeting therapies}

Another potential target for neuroprotection in PD is plasma membrane CAV-1 L-type calcium channel (Ilijic et al. 2011). This concept emerged from the theory of the potentially deleterious consequences of elevated intracellular Ca2+ (Gleichmann et al. 2011) in the vulnerable dopaminergic neurons with strong engagement of CAV-1 L-type Ca2 + channels during autonomous pacemaking (Guzman et al. 2010; Khaliq et al. 2010). Several epidemiologic studies have shown reduced PD risk in patients receiving dihydropyridine calcium channel blockers compared with other antihypertensive agents (Becker et al. 2008; Pasternak et al. 2012; Ritz et al. 2010). Isradipine, a dihydropyridine calcium-channel blocker approved for the treatment of hypertension, has demonstrated a neuroprotective effect (Fig. 1) in animal models of PD (Chan et al. 2007; Guzman et al. 2010; Ilijic et al. 2011), while safety and tolerability of the treatment has been confirmed in clinical trials (Group 2013; Investigators 2020). However, recent results from STEADY-PD III (NCT02168842, Table 2), a 36-month, multicenter, randomized, parallel-group, placebo-controlled trial (Investigators 2020) demonstrated no significant clinical effect of isradipine in progression of early-stage $\mathrm{PD}$, measured as the change of MDS-UPDRS part I to III score in the ON medication state, from baseline to 36 months. Whether the use of higher isradipine dose, or the initiation of treatment with isradipine in even earlier prodromal stages of PD would be more successful is not clear, but better in vivo markers of disease progression and measurement of target engagement are necessary before further studies are undertaken (Maiti et al. 2020).

\section{Iron targeting therapies}

Abnormal iron metabolism is associated with PD and increased intraneuronal iron load has been found in the substantia nigra of patients with PD (Oakley et al. 2007). This increase in iron concentrations can exceed the iron-buffering capacity of complexes, such as neuromelanin and ferritin, and induce neurotoxicity by generating reactive oxygen species (ROS) (Ward et al. 2014). Preclinical studies in animal models of PD demonstrated therapeutic efficacy of iron chelators which could cross the blood-brain barrier, remove excessive intraneuronal iron and reduce ROS formation resulting in increased neuronal survival and normalization of dopamine metabolism (Fig. 1) (Dexter et al. 2011). Results of a phase II, randomized, double-blinded, placebo-controlled, dose-ranging clinical trial on the only 
available blood-brain-barrier-permeable iron chelator deferiprone, in early-PD patients, showed good efficacy and tolerability. Also, region-specific intraneuronal iron load was assessed by T2* MRI and was shown to decrease in the active-treatment groups, but it did not correlate with significant clinical improvement in terms of changes in the UPDRS scores (Martin-Bastida et al. 2017). Deferipone was also assessed in the FairPARK I trial, which applied delayed-start design and showed that earlystart patients had an earlier and more sustainable effect to treatment, both with regard to substantia nigra iron deposit load, and motor symptom severity (Devos et al. 2014). Subsequently, the FairPark II, multi-center trial (NCT02655315, Table 2) was undertaken aiming to evaluate the effect of deferiprone on PD progression measured by the change of total MDS-UPDRS score between baseline and 36 weeks in 372 patients.

\section{A2A receptor antagonists}

In recent years targeting the adenosine $\mathrm{A} 2 \mathrm{~A}$ receptor has emerged as a promising approach for PD treatment (Cieślak et al. 2008). A2A receptor is a member of the G-protein-coupled receptor family that stimulates adenylate cyclase (Zheng et al. 2019), and is highly expressed in the caudate nucleus, putamen, nucleus accumbens, olfactory tubercles and globus pallidus-pars externa (Mori 2014). Several cellular types, including neurons, astrocytes, oligodendrocytes and microglia express the A2A receptor, which is involved in dopaminergic and glutamatergic neurotransmission (Cervetto et al. 2017), neuroinflammation, and neurodegeneration (BorrotoEscuela et al. 2018; Vuorimaa et al. 2017). In terms of pathophysiological mechanisms of $\mathrm{PD}$, the $\mathrm{A} 2 \mathrm{~A}$ receptor attracted attention due to its high striatopallidal expression, specifically in GABAergic and glutamatergic striatopallidal medium spiny neurons (Fig. 1) (Shindou et al. 2001; Shindou et al. 2002; Shindou et al. 2003). A2A and dopamine $D_{2}$ receptors form functional heteromeric complexes inducing allosteric inhibition, and A2A receptor activation results in motor inhibition (Beggiato et al. 2016). Furthermore, A2A receptor interacts physically and functionally with glutamate receptors, primarily with the mGlu5 receptor subtype (Beggiato et al. 2016). This interaction facilitates glutamate release in a synergistic manner (Rodrigues et al. 2005), leading to NMDA glutamate receptor activation and an increase in intracellular $\mathrm{Ca}^{2+}$ concentrations (Glaser et al. 2020). Thus, inhibition of A2A receptor activity, has been a therapeutic target in many preclinical and clinical studies.

After more than two decades of preclinical and clinical studies, istradefylline is the first non-dopaminergic medication approved by FDA for PD (Chen et al. 2020), proven to significantly reduce OFF-time duration, improve motor outcome, as measured by the UPDRS motor score, as well as to increase duration of time without troublesome dyskinesia (Paton 2020). PET studies were first applied to study A2A receptors in-vivo, in PD patients, showing increased expression in the putamen of patients with dyskinesia compared to controls, and a significant increase in drug-naive patients, after initiation of levodopa treatment (Mishina et al. 2011). Subsequent 11 C-preladenant PET studies in PD patients before and after treatment with istradefylline confirmed sufficient, dose-dependent binding of the drug to A2A receptors in the ventral striatum, caudate and the putamen (Ishibashi et al. 2018). Preladenant is another A2A antagonist which, despite positive results in decreasing OFF time in phase II studies (Factor et al. 2013; Hauser et al. 2011), eventually showed no significant clinical efficacy in following phase III trials, either as monotherapy (Stocchi et al. 2017) or in combination with levodopa-treatment (Hauser et al. 2015). However, the lack of efficacy in the active control group treated with rasagiline raises question on possible issues with study design and conduct (Hauser et al. 2015). Tozadenant showed positive effect on reducing OFF-time duration in a phase IIb, double-blind randomized trial (Hauser et al. 2014), but two subsequent phase III trials (NCT02453386 and NCT03051607) were terminated due to an unexpected emerging safety issue. Vipadenant was investigated in an open-label, PET study and showed occupation of A2A receptors varying from 74 to $94 \%$ in human brain regions, including the putamen, at the lowest daily dose of $2.5 \mathrm{mg}$, and reached saturation in all regions at $100 \mathrm{mg}$ (Brooks et al. 2010). Nevertheless, no further investigation was performed with regard to clinical efficacy due to safety concerns. KW-6356 is a secondgeneration $\mathrm{A} 2 \mathrm{~A}$ antagonist which has shown positive results with regard to motor progression in early-stage PD, as assessed by changes in the MDS-UPDRS motor score from baseline until the end of follow-up, both in combination with levodopa (NCT03703570) and as monotherapy (NCT02939391, Table 2) (Chen et al. 2020).

The approval of istradefylline paves the way for novel therapeutic opportunities of A2A antagonists, while underlining the need for identification of patient subgroups that would benefit from these agents. During the last two decades, genetic studies on the effect coffee consumption have provided important insights in the identification of pharmacogenetic markers that are useful in the prediction of individual responses to caffeine, in PD populations (Amin et al. 2012; Hamza et al. 2011; Popat et al. 2011; Yang et al. 2010). These markers could also be useful to define PD subpopulations that are probable responders to treatment with $\mathrm{A} 2 \mathrm{~A}$ receptor antagonists and open the way for personalized therapeutic decisions in this field. 


\section{Cell-replacement therapies}

Even though the very first experiments of cell transplantation in animal brains took place in 1890 (Thompson 1890), it was not until late 1970s in Sweden with the development of the 6-hydroxydopamine-lesioned rat model when neural grafting started gaining attention as a potential therapy for PD (Barker et al. 2015). This model enabled selective and irreversible lesioning of the nigrostriatal pathway (Ungerstedt 1968; Ungerstedt et al. 1970; Ungerstedt et al. 1974), opening the way for assessment of the therapeutic potentials of cell transplantation therapies. Based on these preclinical data, an early clinical study showed that solid grafts of adrenal medullary tissue, known to produce catecholamines, including dopamine, placed into the caudate nucleus through an open microsurgical procedure, had significant benefits in two patients with PD (Madrazo et al. 1987). These studies have been followed by several transplantation trials using either mesencephalic dopaminergic neurons (mesDA) obtained from human fetuses (Lindvall et al. 1990) or, alternatively and more promisingly, dopaminergic cells derived from human pluripotent stem cells (hPSCs) (Barker et al. 2017).

Open label studies demonstrated that fetal mesDA neurons transplantation into the striatum of PD patients had potential for clinical improvement as well as graft survival and function, as assessed by clinical measures, neuroimaging (Brundin et al. 2000; Freed et al. 1992; Hagell et al. 1999; Peschanski et al. 1994; Wenning et al. 1997) and post-mortem histological analysis (Hallett et al. 2014; Kordower et al. 1998; Li et al. 2008; Li et al. 2016; Mendez et al. 2005). Two subsequent randomized, double-blind, sham-surgery-controlled clinical trials showed also some clinical improvement, but did not reach the primary end-points (Freed et al. 2001; Olanow et al. 2003). Although some participants demonstrated normalization of DA signaling accompanied by clinical benefits, others showed no improvement or even experienced adverse effects, mainly graft-induced dyskinesias (Barker et al. 2013; Freed et al. 2001; Olanow et al. 2003). Young patients with early-stage PD and no history of dyskinesias prior to the procedure were more probable to benefit from mesDA neural transplantation (Freed et al. 2001; Olanow et al. 2003). These observations were followed by the formation of the European consortium TRANSEURO (NCT01898390) with the principal objective to develop an efficacious and safe treatment for PD patients based on fetal neural grafting. While completion of the study is not expected until later this year, three years after the last transplantation surgery, which occurred at Skåne University Hospital in Lund, Sweden, in early 2018, a recent update has been published, underlining the potential of emerging stem-cell based dopamine-replacement therapies to provide solutions to the previously encountered issues (Barker et al. 2019). The primary outcome measure in TRANSEURO is the change of MDS-UPDRS part 3 score at 36 months post transplantation and change in F-DOPA-PET is included in the secondary end-points.

hESCs and iPSCs were first reported in 1998 and 2007, respectively, and constituted a renewable source of human cells in very primitive developmental stages capable of differentiating in any cell type in the mature human body (Takahashi et al. 2007; Thomson et al. 1998). Major advantages over fetal-derived cells are the availability in near-unlimited numbers, standardization of manufacture procedures, possibility for cryopreservation, as well as cell purity and the potential for more accurate dosing and distribution through microsurgical procedures (Parmar et al. 2020). Based on these advantages, the GForcePD international corporation was established in 2014 to initiate the first clinical studies of hPSCs transplantation therapies in PD, in Europe, USA, and Japan (Barker et al. 2015).

\section{Brain connectomic studies and improved precision of neuromodulation targets}

The process of altering brain function through direct manipulation of neural activity has long been used to treat patients with neuropsychiatric disorders and deep brain stimulation (DBS) has provided clinical benefit to more than 150000 patients (Horn et al. 2020) with PD, dystonia and essential tremor (Deuschl et al. 2006; Kupsch et al. 2006; Vitek et al. 2020). Apart from the conventional application in advanced PD, DBS has also been suggested to exert disease-modifying traits (McKinnon et al. 2019). In multiple preclinical studies on rat models, chronic STN electrical stimulation was shown to result in preservation of SNpc dopaminergic neurons (Harnack et al. 2008; Spieles-Engemann et al. 2010; Temel et al. 2006) and an increase of brain-derived neurotrophic factors (Spieles-Engemann et al. 2011) followed by activation of the tropomyosin receptor kinase type $B$ receptor signaling in the nigrostriatal system (Yoshii et al. 2010). Although preclinical experiments suggest potential neuroprotective effects of DBS, results from clinical studies have shown that dopaminergic neuron degeneration remains unaltered (Hilker et al. 2005; Pal et al. 2017), and $\alpha$-syn burden is not reduced (Pal et al. 2017) in PD patients treated with DBS (Fig. 1).

The development of diffusion MRI and tractography, as well as the increasing prevalence of large databases and computational bioinformatics, has enabled the visualization of this brain-network connectivity and prompted the proposal of "connectivity surgery" that utilizes diffusion tensor imaging (DTI) tractography as targeting 
modality for DBS-based neural network modulation in movement disorders (Henderson 2012). At the same time, the concept and term of "circuitopathies" was introduced to describe the disturbances of circuit function and brain-network involved in the pathophysiology of several movement disorders and other neurological diseases (Lozano et al. 2013). Normative connectomics, i.e. atlases of average brain connectivity from large cohorts of participants, were firstly presented in 2017 , as a possible predictor of DBS outcome in PD, combining functional and structural connectivity data of open-sourced connectome databases to build a mathematical model that can predict STN-DBS response in patients with PD (Horn et al. 2017). In a recent review, normative connectomics have been compared with patient-specific brain connectivity and have been shown to lead to similar main conclusions about which brain areas are associated with clinical improvement, however patient-specific connectivity profiling was suggested to explain slightly more variance than group connectomes (Wang et al. 2020). Based on these advances, new pathways in neurotherapeutics have opened towards personalized approaches that aim to optimize neuromodulation in a variety of neurological diseases. In a recent, comprehensive overview of DBS technology, the advancements that have contributed to personalized stimulation of specific anatomic structures, real-time record of neural activity and concurrent stimulation adjustments, and identification of key neurocircuitry elements have been highlighted (Krauss et al. 2020). Overview of ongoing DBS trials is beyond the scope of this review.

\section{Focused ultrasound as a newly developed neuromodulation technique}

Magnetic resonance imaging-guided focused ultrasound (MRgFUS) neurosurgery is emerging as a new option for the treatment of medication-resistant PD. The technique is based on focusing ultrasound beams to specific brain target causing protein denaturation and coagulation necrosis (Harary et al. 2018). Advances in MRI technology have enabled real-time guidance of the procedure by using MR thermometry, facilitating localization of the target below the threshold temperature and ablation of the target above the threshold temperature (Harary et al. 2018). Compared with DBS, MRgFUS neurosurgery appears safe and effective against motor symptoms in PD (Xu et al. 2019), but larger studies with long follow-up are needed to support these results. The first application in PD was performed in 13 medication-resistant patients that received MRgFUS pallidothalamic tractotomy and had a significant UPDRS score reduction at 3 months post intervention, thus indicating feasibility, safety, and accuracy of the method (Magara et al. 2014). In another study, 30 patients with severe PD-related, medicationresistant tremor received MRgFUS and were followed for 1 to 24 months, during which time UPDRS part 2 and PDQ39 scores improved significantly by 6 months, but tremor recurred in 4 patients by 6 to 24 months (Zaaroor et al. 2018). Additional studies in tremor-dominant PD patients (Bond et al. 2017; Fasano et al. 2017; Sperling et al. 2018) and a phase 1 trial in PD dyskinesia showed partly positive results, but were limited by the short follow-up and small patient groups. To date, existing evidence supports the use of MRgFUS to achieve longterm benefits in refractory essential tremor (Meng et al. 2018; Sinai et al. 2019), but further research is required in PD. Several clinical trials (Table 1) are currently ongoing to evaluate the method as a potential therapy in PD symptoms such as dyskinesias and motor fluctuations (NCT02347254, NCT02003248, NCT04002596, NCT03319485, NCT02263885, NCT02246374, NCT03100474). Interestingly, an ongoing study plans to evaluate the application of MRgFUS for the temporary disruption of the blood brain barrier as a potential therapeutic strategy for PD dementia, as well as an effort to overcome problematic pharmaceutical agents' delivery in their targets of action inside the CNS (NCT03608553, Table 1).

\section{Repetitive transcranial magnetic stimulation}

Transcranial Magnetic Stimulation (TMS) is a safe and noninvasive technique of electromagnetic brain stimulation (Burke et al. 2019). TMS can probe intracortical circuits and alter cortical activity in the human brain (Fig. 1), where repetitive application has been of therapeutic value in neurological and psychiatric disorders by normalizing aberrant patterns of cortical activity (Burke et al. 2019). Repetitive TMS (rTMS) has been FDA approved for the treatment of mild to moderate medication-resistant depression (Rossi et al. 2009), which has prompted further investigation of its efficacy on a wide range of neuropsychiatric circuitopathies including PD.

rTMS administered over primary frontal cortex at high frequency has been shown to moderately improve motor outcome in PD patients with an average $20 \%$ reduction in the UPDRS motor score (Brys et al. 2016; Khedr et al. 2003; Kim et al. 2015; Yang et al. 2018; Yokoe et al. 2018). In these studies, motor outcome was improved both in the upper and lower extremities independently of the TMS target on hand or foot cortical region, presumably due to plasticity alterations in circuits supplying corticospinal neurons both on proximal and distant brain areas (Underwood et al. 2020). Despite these encouraging results, the need for frequent clinical visits in PD applications has a negative impact on compliance, which can be intensified by mobility issues, as well as the long 
duration of TMS sessions (Berlim et al. 2014; Yang et al. 2018). Ongoing trials aim to further evaluate the effect of rTMS on PD motor outcome in terms of walking ability as assessed by step variability, step length and gait speed in dual-task walking (NCT04238000, Table 1), and freezing of gait assessed by the change of freezing of gait questionnaire (NCT04431570, Table 1). A phase 2, triple blind, randomized study (NCT04116216, Table 1) aims to investigate whether patients with different PD phenotypes will respond differently to rTMS, as well as to compare the effects of rTMS protocols (high vs. low frequency).

Few studies have investigated the effect of rTMS on levodopa-induced dyskinesias, showing only short-lasting (Brusa et al. 2006; Filipovic et al. 2009; Koch et al. 2005; Sayin et al. 2014; Wagle-Shukla et al. 2007) or no (Flamez et al. 2016) beneficial effect.

Current studies focus on the therapeutic potential of rTMS in PD-associated cognitive dysfunction. A phase 2 , randomized controlled trial with quadruple masking including 166 patients with PD mild cognitive impairment (MCI) (NCT03836950, Table 1) will primarily evaluate the effect of rTMS on executive function. Multimodal neuroimaging will be used in a subgroup of participants to study rTMS-induced neural connectivity changes. Changes in resting state functional connectivity, grey matter volume via voxel-based morphometry and white matter integrity via diffusion tensor imaging between baseline and endpoint will also be assessed. Similarly, in another double blind, randomized trial (NCT02346708, Table 1) 150 patients with PD-MCI will receive bifrontal rTMS and will be assessed by changes in magnetoencephalography connectivity measures as well as clinical cognitive scores. Finally, a ten-center, blinded, sham-controlled, randomized, parallel-group study of fixed-dose, high-frequency and/or low-frequency rTMS in 252 PD patients with depression or cognitive impairment (NCT03552861, Table 1) aims to evaluate the effect of rTMS as an alternative treatment with respect to these common PD symptoms.

\section{Conclusions}

In conclusion, current trends in PD research have moved from dopamine-replenishing, symptomatic therapies to personalized treatments targeted to the restoration of molecular, anatomical and functional integrity of disease-specific brain circuits. Significant technological advances in gene manipulation methods, DBS devices and software, and neuroimaging, in combination with increased awareness of the methodological issues that have so far hampered PD therapeutic research have led to novel pharmacotherapeutic and non-pharmacological strategies that are under ongoing assessment. Additionally, advances in biomarker research and identification of robust, presumably multimodal, markers of pathogenesis and disease progression are of utmost importance for the successful conduct of PD clinical trials aiming to fill the long-lasting deficit in disease modifying, individually tailored treatment options.

\begin{abstract}
Abbreviations
AADC: Aromatic L-amino acid decarboxylase; AAV: Adeno- associated virus; AAV2: Adeno-associated virus serotype 2; ASO: Anti-sense oligonucleotide; CNS: Central nervous system; DaTscan: Dopamine transporter scan; DBS: Deep brain stimulation; DNA: Deoxyribonucleic acid; ER: Endoplasmic reticulum; FDA: Food and drug administration.; ${ }^{18} \mathrm{~F}-\mathrm{FDG}-\mathrm{PET}:{ }^{18} \mathrm{~F}$-fluorodexyglucose positron emission tomography; GAD: Glutamate decarboxylase; GADA: Gamma-aminobutyric acid; GCase: Glucocerebrosidase; GCH1: GTP-cyclohydrolase; GDNF: Glial cell-line derived neurotrophic factor; GLP1: Glucagon-like peptide-1; GSR: Global symptom relief; HDRS: Hamilton Depression Rating Scale; hESCs: Human embryonic stem cells; HLA: Human leucocyte antigen; hPSCs: Human pluripotent stem cells; HSP: Heat shock protein; iPSCs: Induced pluripotent stem cells; LRRK2: Leukine-rich repeat kinase 2; LV: Lentivirus; MADRS: Montgomery-Åsberg Depression Rating Scale; MCI: Mild cognitive impairment; MesDA: mesencephalic dopaminergic; MRgFUS: Magnetic resonance imaging-guided focused ultrasound; MRI: Magnetic resonance imaging; NRTN: Neurturin; PD: Parkinson's disease; PDQ-39: Parkinson's disease questionnaire - 39; PET: Positron emission tomography; RA: Receptor agonist; RNA: Ribonucleic acid; ROC: Ras-of-complex; ROS: Reactive oxygen species; rTMS: Repetitive transcranial magnetic stimulation; STN: Subthalamic nucleus; T2DM: Type 2 diabetes mellitus; TH: Tyrosine hydroxylase; TMS: Transcranial magnetic stimulation; UPDRS: Unified Parkinson Disease Rating Scale; a-synuclein: a-syn.
\end{abstract}

\section{Acknowledgements}

The authors would like to thank Dr. loannis Mantas for his help with the illustration included in this Review.

\section{Authors' contributions}

TN, EP and IM wrote the review together. All authors read and approved the final manuscript.

\section{Funding}

Open access funding provided by Karolinska Institute. IM receives funding by Stockholm County Council, grant number 2018020; Neuro Fund Stockholm and Parkinson Research Foundation-Stockholm.

Availability of data and materials

Not applicable.

Ethics approval and consent to participate

Not applicable.

Consent for publication

Not applicable.

Competing interests

The authors declare thatthey have no competing interests.

\section{Author details \\ ${ }^{1}$ Department of Clinical Neuroscience, Karolinska Institutet, Stockholm, Sweden. ${ }^{2}$ Center of Neurology, Academic Specialist Center, Solnavägen $1 \mathrm{E}$, 11365 Stockholm, Sweden. ${ }^{3}$ Department of Neurology, Danderyd Hospital Stockholm, Stockholm, Sweden.}

Received: 3 December 2020 Revised: 3 February 2021 Accepted: 8 February 2021

Published online: 25 February 2021 


\section{References}

Aflaki E, Westbroek W, Sidransky E. The complicated relationship between gaucher disease and parkinsonism: insights from a rare disease. Neuron. 2017;93(4):737-46.

Albin RL, Young AB, Penney JB. The functional anatomy of basal ganglia disorders. Trends Neurosci. 1989;12(10):366-75.

Alvarez E, Martinez MD, Roncero I, et al. The expression of GLP-1 receptor mRNA and protein allows the effect of GLP-1 on glucose metabolism in the human hypothalamus and brainstem. J Neurochem. 2005;92(4):798-806.

Alzforum. (2020) Parkinson's therapies seek to stem progression. In: Book Parkinson's therapies seek to stem progression. https://www.alzforum. org/news/conference-coverage/parkinsons-therapies-seek-stem-progr ession. Accessed 19 Jan 2021.

Amin N, Byrne E, Johnson J, et al. Genome-wide association analysis of coffee drinking suggests association with CYP1A1/CYP1A2 and NRCAM. Mol Psychiatry. 2012;17(11):1116-29.

Apolonia L, Waddington SN, Fernandes C, et al. Stable gene transfer to muscle using non-integrating lentiviral vectors. Mol Ther. 2007;15(11):1947-54.

Armstrong MJ, Okun MS. Diagnosis and treatment of Parkinson disease: a review. JAMA. 2020;323(6):548-60.

Athauda D, Gulyani S, Karnati HK, et al. Utility of neuronal-derived exosomes to examine molecular mechanisms that affect motor function in patients with Parkinson disease: a secondary analysis of the exenatide-PD trial. JAMA Neurol. 2019;76(4):420-9.

Athauda D, Maclagan K, Skene SS, et al. Exenatide once weekly versus placebo in Parkinson's disease: a randomised, double-blind, placebo-controlled trial. Lancet. 2017. https://doi.org/10.1016/S0140-6736(17)31585-4.

Axelsen TM, Woldbye DPD. Gene therapy for Parkinson's disease, an update. J Parkinsons Dis. 2018;8(2):195-215.

Baggio LL, Drucker DJ. Biology of incretins: GLP-1 and GIP. Gastroenterology. 2007;132(6):2131-57.

Barker RA, Barrett J, Mason SL, Björklund A. Fetal dopaminergic transplantation trials and the future of neural grafting in Parkinson's disease. Lancet Neurol. 2013;12(1):84-91.

Barker RA , Consortium T. Designing stem-cell-based dopamine cell replacement trials for Parkinson's disease. Nat Med. 2019;25(7):1045-53.

Barker RA, Drouin-Ouellet J, Parmar M. Cell-based therapies for Parkinson disease-past insights and future potential. Nat Rev Neurol. 2015;11(9):492-503.

Barker RA, Parmar M, Studer L, Takahashi J. Human trials of stem cell-derived dopamine neurons for Parkinson's disease: dawn of a new era. Cell Stem Cell. 2017;21(5):569-73.

Barker RA, Studer L, Cattaneo E, Takahashi J, Consortium GFP. G-Force PD: a global initiative in coordinating stem cell-based dopamine treatments for Parkinson's disease. NPJ Parkinson's Dis. 2015;1:15017.

Bassil F, Canron MH, Vital A, et al. Insulin resistance and exendin-4 treatment for multiple system atrophy. Brain. 2017;140(5):1420-36

Beach TG, Adler CH, Sue LI, et al. Multi-organ distribution of phosphorylated alpha-synuclein histopathology in subjects with Lewy body disorders. Acta Neuropathol. 2010;119(6):689-702.

Becker C, Jick SS, Meier CR. Use of antihypertensives and the risk of Parkinson disease. Neurology. 2008;70(16 Pt 2):1438-44.

Beggiato S, Tomasini MC, Borelli AC, et al. Functional role of striatal A2A, D2, and $m$ Glu5 receptor interactions in regulating striatopallidal GABA neuronal transmission. J Neurochem. 2016;138(2):254-64.

Bendikov-Bar I, Maor G, Filocamo M, Horowitz M. Ambroxol as a pharmacological chaperone for mutant glucocerebrosidase. Blood Cells Mol Dis. 2013;50(2):141-5.

Bengoa-Vergniory N, Faggiani E, Ramos-Gonzalez P, et al. CLR01 protects dopaminergic neurons in vitro and in mouse models of Parkinson's disease. Nat Commun. 2020;11(1):4885

Berlim MT, van den Eynde F, Tovar-Perdomo S, Daskalakis ZJ. Response, remission and drop-out rates following high-frequency repetitive transcranial magnetic stimulation (rTMS) for treating major depression: a systematic review and meta-analysis of randomized, double-blind and sham-controlled trials. Psychol Med. 2014;44(2):225-39.

Berns KI, Muzyczka N. AAV: an overview of unanswered questions. Hum Gene Ther. 2017;28(4):308-13.

Bertilsson G, Patrone C, Zachrisson O, et al. Peptide hormone exendin-4 stimulates subventricular zone neurogenesis in the adult rodent brain and induces recovery in an animal model of Parkinson's disease. J Neurosci Res. 2008;86(2):326-38.

Beutler E, Grabowski GA. Glucosylceramide lipidosis-Gaucher disease. In: Scriver CR, Beaudet AL, Sly WS, Valle D, editors. The metabolic and molecular basis of inherited disease. 8th ed. McGraw Hill; 2001.

Bevan AK, Duque S, Foust KD, et al. Systemic gene delivery in large species for targeting spinal cord, brain, and peripheral tissues for pediatric disorders. Mol Ther. 2011;19(11):1971-80.

Boer DEC, van Smeden J, Bouwstra JA, Aerts JMFG. Glucocerebrosidase: functions in and beyond the lysosome. J Clin Med. 2020;9(3):736.

Bond AE, Shah BB, Huss DS, et al. Safety and efficacy of focused ultrasound thalamotomy for patients with medication-refractory, tremordominant Parkinson disease: a randomized clinical trial. JAMA Neurol. 2017;74(12):1412-8.

Borel F, Kay MA, Mueller C. Recombinant AAV as a platform for translating the therapeutic potential of RNA interference. Mol Ther. 2014;22(4):692-701.

Borroto-Escuela DO, Hinz S, Navarro G, Franco R, Müller CE, Fuxe K. Understanding the role of adenosine A2AR heteroreceptor complexes in neurodegeneration and neuroinflammation. Front Neurosci. 2018;12:43.

Braak H, Del Tredici K, Rub U, de Vos RA, Jansen Steur EN, Braak E. Staging of brain pathology related to sporadic Parkinson's disease. Neurobiol Aging. 2003;24(2):197-211.

Brockmann K, Srulijes K, Pflederer S, et al. GBA-associated Parkinson's disease: reduced survival and more rapid progression in a prospective longitudinal study. Mov Disord. 2015;30(3):407-11.

Brooks DJ, Papapetropoulos S, Vandenhende F, et al. An open-label, positron emission tomography study to assess adenosine A2A brain receptor occupancy of vipadenant (BIIB014) at steady-state levels in healthy male volunteers. Clin Neuropharmacol. 2010;33(2):55-60.

Brundin P, Pogarell O, Hagell P, et al. Bilateral caudate and putamen grafts of embryonic mesencephalic tissue treated with lazaroids in Parkinson's disease. Brain. 2000;123(Pt 7):(1380-90.

Brusa L, Versace V, Koch G, et al. Low frequency rTMS of the SMA transiently ameliorates peak-dose LID in Parkinson's disease. Clin Neurophysiol. 2006;117(9):1917-21.

Brys M, Fox MD, Agarwal S, et al. Multifocal repetitive TMS for motor and mood symptoms of Parkinson disease: a randomized trial. Neurology. 2016;87(18):1907-15.

Burke MJ, Fried PJ, Pascual-Leone A. Transcranial magnetic stimulation: neurophysiological and clinical applications. Handb Clin Neurol. 2019:163:73-92.

Cearley $\mathrm{CN}$, Wolfe $\mathrm{JH}$. A single injection of an adeno-associated virus vector into nuclei with divergent connections results in widespread vector distribution in the brain and global correction of a neurogenetic disease. J Neurosci. 2007;27(37):9928-40.

Cedarbaum JM, Elephants. Parkinson's disease, and proof-of-concept clinical trials. Mov Disord. 2018;33(5):697-700.

Cervetto C, Venturini A, Passalacqua M, et al. A2A-D2 receptor-receptor interaction modulates gliotransmitter release from striatal astrocyte processes. J Neurochem. 2017;140(2):268-79.

Chan CS, Guzman JN, Ilijic E, et al. 'Rejuvenation' protects neurons in mouse models of Parkinson's disease. Nature. 2007:447(7148):1081-6.

Chan SL, Tan EK. Targeting LRRK2 in Parkinson's disease: an update on recent developments. Expert Opin Ther Targets. 2017:21(6):601-10.

Chen J, Chen Y, Pu J. Leucine-rich repeat kinase 2\&nbsp;in Parkinson's disease: updated from pathogenesis to potential therapeutic target. Eur Neurol. 2018:79(5-6):256-65.

Chen JF, Cunha RA. The belated US FDA approval of the adenosine A. Purinergic Signal. 2020;16(2):167-74

Choi JH, Stubblefield B, Cookson MR, et al. Aggregation of a-synuclein in brain samples from subjects with glucocerebrosidase mutations. Mol Genet Metab. 2011;104(1-2):185-8.

Christine CW, Bankiewicz KS, Van Laar AD, et al. Magnetic resonance imagingguided phase 1 trial of putaminal AADC gene therapy for Parkinson's disease. Ann Neurol. 2019;85(5):704-14.

Christine CW, Starr PA, Larson PS, et al. Safety and tolerability of putaminal AADC gene therapy for Parkinson disease. Neurology. 2009;73(20):1662-9.

Cieślak M, Komoszyński M, Wojtczak A. Adenosine A(2A) receptors in Parkinson's disease treatment. Purinergic Signal. 2008;4(4):305-12. 
Cookson MR. Mechanisms of mutant LRRK2 neurodegeneration. Adv Neurobiol. 2017;14:227-39.

Coune PG, Schneider BL, Aebischer P. Parkinson's disease: gene therapies. Cold Spring Harb Perspect Med. 2012;2(4):a009431.

Cresto N, Gardier C, Gubinelli F, et al. The unlikely partnership between LRRK2 and a-synuclein in Parkinson's disease. Eur J Neurosci. 2019:49(3):339-63.

Cronin J, Zhang XY, Reiser J. Altering the tropism of lentiviral vectors through pseudotyping. Curr Gene Ther. 2005;5(4):387-98.

Daher JP, Abdelmotilib HA, Hu X, et al. Leucine-rich repeat kinase 2 (LRRK2) pharmacological inhibition abates a-synuclein gene-induced neurodegeneration. J Biol Chem. 2015;290(32):19433-44.

Daher JP, Volpicelli-Daley LA, Blackburn JP, Moehle MS, West AB. Abrogation of a-synuclein-mediated dopaminergic neurodegeneration in LRRK2deficient rats. Proc Natl Acad Sci U S A. 2014;111(25):9289-94.

De Silva A, Salem V, Long CJ, et al. The gut hormones PYY 3-36 and GLP-1 7-36 amide reduce food intake and modulate brain activity in appetite centers in humans. Cell Metab. 2011;14(5):700-6.

Dehay B, Dalkara D, Dovero S, Li Q, Bezard E. Systemic scAAV9 variant mediates brain transduction in newborn rhesus macaques. Sci Rep. 2012;2:253.

Deuschl G, Schade-Brittinger C, Krack P, et al. A randomized trial of deep-brain stimulation for Parkinson's disease. N Engl J Med. 2006;355(9):896-908.

Devos D, Moreau C, Devedjian JC, et al. Targeting chelatable iron as a therapeutic modality in Parkinson's disease. Antioxid Redox Signal. 2014;21(2):195-210

Dexter DT, Statton SA, Whitmore C, et al. Clinically available iron chelators induce neuroprotection in the 6-OHDA model of Parkinson's disease after peripheral administration. J Neural Transm (Vienna). 2011;118(2):223-31.

Dominguez E, Marais T, Chatauret N, et al. Intravenous scAAV9 delivery of a codon-optimized SMN1 sequence rescues SMA mice. Hum Mol Genet. 2011;20(4):681-93.

Dull T, Zufferey R, Kelly M, et al. A third-generation lentivirus vector with a conditional packaging system. J Virol. 1998;72(11):8463-71.

Duque S, Joussemet B, Riviere C, et al. Intravenous administration of self-complementary AAV9 enables transgene delivery to adult motor neurons. Mol Ther. 2009;17(7):1187-96.

Erlander MG, Tillakaratne NJ, Feldblum S, Patel N, Tobin AJ. Two genes encode distinct glutamate decarboxylases. Neuron. 1991;7(1):91-100.

Espay AJ, Hauser RA, Armstrong MJ. The narrowing path for nilotinib and other potential disease-modifying therapies for parkinson disease. JAMA Neurol. 2020;77(3):295-7.

Espay AJ, Morgante F, Merola A, et al. Levodopa-induced dyskinesia in Parkinson disease: current and evolving concepts. Ann Neurol. 2018;84(6):797-811.

Factor SA, Wolski K, Togasaki DM, et al. Long-term safety and efficacy of preladenant in subjects with fluctuating Parkinson's disease. Mov Disord. 2013;28(6):817-20.

Fan R, Li X, Gu X, Chan JC, Xu G. Exendin-4 protects pancreatic beta cells from human islet amyloid polypeptide-induced cell damage: potential involvement of AKT and mitochondria biogenesis. Diabetes Obes Metab. 2010;12(9):815-24.

Fasano A, Llinas M, Munhoz RP, Hlasny E, Kucharczyk W, Lozano AM. MRIguided focused ultrasound thalamotomy in non-ET tremor syndromes. Neurology. 2017:89(8):771-5.

Fiandaca MS, Bankiewicz KS. Gene therapy for Parkinson's disease: from nonhuman primates to humans. Curr Opin Mol Ther. 2010;12(5):519-29.

Fiandaca MS, Varenika V, Eberling J, et al. Real-time MR imaging of adenoassociated viral vector delivery to the primate brain. Neuroimage. 2009;47(Suppl 2):T27-35

Filipovic SR, Rothwell JC, van de Warrenburg BP, Bhatia K. Repetitive transcranial magnetic stimulation for levodopa-induced dyskinesias in Parkinson's disease. Mov Disord. 2009;24(2):246-53.

Flamez A, Cordenier A, De Raedt S, et al. Bilateral low frequency rTMS of the primary motor cortex may not be a suitable treatment for levodopainduced dyskinesias in late stage Parkinson's disease. Parkinsonism Relat Disord. 2016;22:54-61.

Foust KD, Wang X, McGovern VL, et al. Rescue of the spinal muscular atrophy phenotype in a mouse model by early postnatal delivery of SMN. Nat Biotechnol. 2010;28(3):271-4.
Freed CR, Breeze RE, Rosenberg NL, et al. Survival of implanted fetal dopamine cells and neurologic improvement 12 to 46 months after transplantation for Parkinson's disease. N Engl J Med. 1992;327(22):1549-55.

Freed CR, Greene PE, Breeze RE, et al. Transplantation of embryonic dopamine neurons for severe Parkinson's disease. N Engl J Med. 2001;344(10):710-9.

Funayama M, Hasegawa K, Kowa H, Saito M, Tsuji S, Obata F. A new locus for Parkinson's disease (PARK8) maps to chromosome 12p11.2-q13.1. Ann Neurol. 2002:51(3):296-301.

Gan-Or Z, Liong C, Alcalay RN. GBA-associated Parkinson's disease and other synucleinopathies. Curr Neurol Neurosci Rep. 2018;18(8):44.

Gao G, Vandenberghe LH, Wilson JM. New recombinant serotypes of AAV vectors. Curr Gene Ther. 2005:5(3):285-97.

Gash DM, Zhang Z, Ovadia A, et al. Functional recovery in parkinsonian monkeys treated with GDNF. Nature. 1996;380(6571):252-5.

Gaston J, Maestrali N, Lalle G, et al. Intracellular delivery of therapeutic antibodies into specific cells using antibody-peptide fusions. Sci Rep. 2019:9(1):18688.

Gijsbers R, Ronen K, Vets S, et al. LEDGF hybrids efficiently retarget lentiviral integration into heterochromatin. Mol Ther. 2010;18(3):552-60.

Gill SS, Patel NK, Hotton GR, et al. Direct brain infusion of glial cell line-derived neurotrophic factor in Parkinson disease. Nat Med. 2003;9(5):589-95.

Glaser T, Andrejew R, Oliveira-Giacomelli Á, et al. Purinergic receptors in basal ganglia diseases: shared molecular mechanisms between Huntington's and Parkinson's Disease. Neurosci Bull. 2020. https://doi.org/10.1007/ s12264-020-00582-8.

Gleichmann M, Mattson MP. Neuronal calcium homeostasis and dysregulation. Antioxid Redox Signal. 2011;14(7):1261-73.

Gorbatyuk OS, Li S, Nash K, et al. In vivo RNAi-mediated alpha-synuclein silencing induces nigrostriatal degeneration. Mol Ther. 2010;18(8):1450-7.

Group PS. Phase II safety, tolerability, and dose selection study of isradipine as a potential disease-modifying intervention in early Parkinson's disease (STEADY-PD). Mov Disord. 2013;28(13):1823-31.

Guzman JN, Sanchez-Padilla J, Wokosin D, et al. Oxidant stress evoked by pacemaking in dopaminergic neurons is attenuated by DJ-1. Nature. 2010:468(7324):696-700.

Hagell P, Schrag A, Piccini P, et al. Sequential bilateral transplantation in Parkinson's disease: effects of the second graft. Brain. 1999;122(Pt 6):(1121-32.

Haggerty DL, Grecco GG, Reeves KC, Atwood B. Adeno-Associated Viral Vectors in Neuroscience Research. Mol Ther Methods Clin Dev. 2020;17:69-82.

Hallett PJ, Cooper O, Sadi D, Robertson H, Mendez I, Isacson O. Long-term health of dopaminergic neuron transplants in Parkinson's disease patients. Cell Rep. 2014;7(6):1755-61.

Hamza TH, Chen H, Hill-Burns EM, et al. Genome-wide gene-environment study identifies glutamate receptor gene GRIN2A as a Parkinson's disease modifier gene via interaction with coffee. PLoS Genet. 2011;7(8):e1002237.

Han H, Yang J, Chen W, Li Q, Yang Y. A comprehensive review on histone-mediated transfection for gene therapy. Biotechnol Adv. 2019;37(1):132-44.

Hanlon KS, Meltzer JC, Buzhdygan T, et al. Selection of an efficient AAV vector for robust CNS transgene expression. Mol Ther Methods Clin Dev. 2019;15:320-32.

Harary M, Segar DJ, Huang KT, Tafel IJ, Valdes PA, Cosgrove GR. Focused ultrasound in neurosurgery: a historical perspective. Neurosurg Focus. 2018:44(2):E2.

Harkavyi A, Abuirmeileh A, Lever R, Kingsbury AE, Biggs CS, Whitton PS. Glucagon-like peptide 1 receptor stimulation reverses key deficits in distinct rodent models of Parkinson's disease. J Neuroinflammation. 2008;5:19.

Harnack D, Meissner W, Jira JA, Winter C, Morgenstern R, Kupsch A. Placebocontrolled chronic high-frequency stimulation of the subthalamic nucleus preserves dopaminergic nigral neurons in a rat model of progressive Parkinsonism. Exp Neurol. 2008;210(1):257-60.

Hauser RA, Cantillon M, Pourcher E, et al. Preladenant in patients with Parkinson's disease and motor fluctuations: a phase 2, double-blind randomised trial. Lancet Neurol. 2011;10(3):221-9.

Hauser RA, Olanow CW, Kieburtz KD, et al. Tozadenant (SYN115) in patients with Parkinson's disease who have motor fluctuations on levodopa: a phase 2b, double-blind, randomised trial. Lancet Neurol. 2014;13(8):767-76. 
Hauser RA, Stocchi F, Rascol O, et al. Preladenant as an adjunctive therapy with levodopa in Parkinson disease: two randomized clinical trials and lessons learned. JAMA Neurol. 2015;72(12):1491-500.

Healy DG, Falchi M, O'Sullivan SS, et al. Phenotype, genotype, and worldwide genetic penetrance of LRRK2-associated Parkinson's disease: a casecontrol study. Lancet Neurol. 2008;7(7):583-90.

Heiss JD, Lungu C, Hammoud DA, et al. Trial of magnetic resonance-guided putaminal gene therapy for advanced Parkinson's disease. Mov Disord. 2019;34(7):1073-8.

Henderson JM. "Connectomic surgery": diffusion tensor imaging (DTI) tractography as a targeting modality for surgical modulation of neural networks. Front Integr Neurosci. 2012;6:15.

Herzig MC, Kolly C, Persohn E, et al. LRRK2 protein levels are determined by kinase function and are crucial for kidney and lung homeostasis in mice. Hum Mol Genet. 2011;20(21):4209-23.

Hilker R, Portman AT, Voges J, et al. Disease progression continues in patients with advanced Parkinson's disease and effective subthalamic nucleus stimulation. J Neurol Neurosurg Psychiatry. 2005;76(9):1217-21.

Horn A, Fox MD. Opportunities of connectomic neuromodulation. Neuroimage. 2020;221:117180

Horn A, Reich M, Vorwerk J, et al. Connectivity predicts deep brain stimulation outcome in Parkinson disease. Ann Neurol. 2017:82(1):67-78.

Hoy SM. Onasemnogene abeparvovec: first global approval. Drugs. 2019;79(11):1255-62.

Hoyer S. Is sporadic Alzheimer disease the brain type of non-insulin dependent diabetes mellitus? A challenging hypothesis. J Neural Transm (Vienna). 1998;105(4-5):415-22.

Hudry E, Vandenberghe LH. Therapeutic AAV gene transfer to the nervous system: a clinical reality. Neuron. 2019;101(5):839-62.

Ilijic E, Guzman JN, Surmeier DJ. The L-type channel antagonist isradipine is neuroprotective in a mouse model of Parkinson's disease. Neurobiol Dis. 2011;43(2):364-71.

Investigators PSGS-PI. Isradipine versus placebo in early Parkinson disease: a randomized trial. Ann Intern Med. 2020;172(9):591-8.

Ishibashi K, Miura Y, Wagatsuma K, Toyohara J, Ishiwata K, Ishii K. Occupancy of adenosine A2A receptors by istradefylline in patients with Parkinson's disease using (11)C-preladenant PET. Neuropharmacology. 2018;143:106-12.

Jahanshahi M, Obeso I, Baunez C, Alegre M, Krack P. Parkinson's disease, the subthalamic nucleus, inhibition, and impulsivity. Mov Disord. 2015;30(2):128-40.

Jankovic J. Levodopa strengths and weaknesses. Neurology. 2002;58(4 Suppl 1):19-32.

Jankovic J, Goodman I, Safirstein B, et al. Safety and Tolerability of Multiple Ascending Doses of PRX002/RG7935, an Anti-alpha-Synuclein Monoclonal Antibody, in Patients With Parkinson Disease: A Randomized Clinical Trial. JAMA Neurol. 2018;75(10):1206-14.

Jowaed A, Schmitt I, Kaut O, Wullner U. Methylation regulates alpha-synuclein expression and is decreased in Parkinson's disease patients'brains. J Neurosci. 2010;30(18):6355-9.

Kantor B, Bailey RM, Wimberly K, Kalburgi SN, Gray SJ. Methods for gene transfer to the central nervous system. Adv Genet. 2014;87:125-97.

Kantor B, Bayer M, Ma H, et al. Notable reduction in illegitimate integration mediated by a PPT-deleted, nonintegrating lentiviral vector. Mol Ther. 2011;19(3):547-56.

Kantor B, Tagliafierro L, Gu J, et al. Downregulation of SNCA expression by targeted editing of DNA methylation: a potential strategy for precision therapy in PD. Mol Ther. 2018;26(11):2638-49.

Kaplitt MG, Feigin A, Tang C, et al. Safety and tolerability of gene therapy with an adeno-associated virus (AAV) borne GAD gene for Parkinson's disease: an open label, phase I trial. Lancet. 2007;369(9579):2097-105.

Kells AP, Eberling J, Su X, et al. Regeneration of the MPTP-lesioned dopaminergic system after convection-enhanced delivery of AAV2-GDNF. J Neurosci. 2010;30(28):9567-77.

Kett LR, Dauer WT. Leucine-rich repeat kinase 2 for beginners: six key questions. Cold Spring Harb Perspect Med. 2012;2(3):a009407.

Khaliq ZM, Bean BP. Pacemaking in dopaminergic ventral tegmental area neurons: depolarizing drive from background and voltage-dependent sodium conductances. J Neurosci. 2010;30(21):7401-13.
Khedr EM, Farweez HM, Islam H. Therapeutic effect of repetitive transcranial magnetic stimulation on motor function in Parkinson's disease patients. Eur J Neurol. 2003;10(5):567-72.

Kim MS, Chang WH, Cho JW, et al. Efficacy of cumulative high-frequency rTMS on freezing of gait in Parkinson's disease. Restor Neurol Neurosci. 2015;33(4):521-30.

Khanna RP, Soska L, Lun R, Feng Y, Frascella J, Ranes M, Guillen BE, Garcia D, Flanagan A, Lockhart JF, Clark DJ, Valenzano SW. Exploring the use of pharmacological chaperone AT3375 alone and in combination with recombinant human B-glucosidase for gaucher disease. Mol Genet Metab. 2012;105(2):40.

Kim S, Moon M, Park S. Exendin-4 protects dopaminergic neurons by inhibition of microglial activation and matrix metalloproteinase-3 expression in an animal model of Parkinson's disease. J Endocrinol. 2009:202(3):431-9.

Kish SJ, Shannak K, Hornykiewicz O. Uneven pattern of dopamine loss in the striatum of patients with idiopathic Parkinson's disease. Pathophysiologic and clinical implications. N Engl J Med. 1988;318(14):876-80.

Koch G, Brusa L, Caltagirone C, et al. rTMS of supplementary motor area modulates therapy-induced dyskinesias in Parkinson disease. Neurology. 2005;65(4):623-5.

Kordower JH, Freeman TB, Chen EY, et al. Fetal nigral grafts survive and mediate clinical benefit in a patient with Parkinson's disease. Mov Disord. 1998;13(3):383-93.

Kotzbauer PT, Lampe PA, Heuckeroth RO, et al. Neurturin, a relative of glial-cellline-derived neurotrophic factor. Nature. 1996;384(6608):467-70.

Krauss JK, Lipsman N, Aziz T, et al. Technology of deep brain stimulation: current status and future directions. Nat Rev Neurol. 2020. https://doi. org/10.1038/s41582-020-00426-z.

Kupsch A, Benecke R, Müller J, et al. Pallidal deep-brain stimulation in primary generalized or segmental dystonia. N Engl J Med. 2006:355(19):1978-90.

Lee SE, Lee Y, Lee GH. The regulation of glutamic acid decarboxylases in GABA neurotransmission in the brain. Arch Pharm Res. 2019;42(12):1031-9.

LeWitt PA, Rezai AR, Leehey MA, et al. AAV2-GAD gene therapy for advanced Parkinson's disease: a double-blind, sham-surgery controlled, randomised trial. Lancet Neurol. 2011;10(4):309-19.

Li JY, Englund E, Holton JL, et al. Lewy bodies in grafted neurons in subjects with Parkinson's disease suggest host-to-graft disease propagation. Nat Med. 2008;14(5):501-3.

Li W, Englund E, Widner $\mathrm{H}$, et al. Extensive graft-derived dopaminergic innervation is maintained 24 years after transplantation in the degenerating parkinsonian brain. Proc Natl Acad Sci U S A. 2016;113(23):6544-9.

Li Y, Perry T, Kindy MS, et al. GLP-1 receptor stimulation preserves primary cortical and dopaminergic neurons in cellular and rodent models of stroke and Parkinsonism. Proc Natl Acad Sci U S A. 2009;106(4):1285-90.

Lieberman RL, D'aquino JA, Ringe D, Petsko GA. Effects of pH and iminosugar pharmacological chaperones on lysosomal glycosidase structure and stability. Biochemistry. 2009;48(22):4816-27.

Lin LF, Doherty DH, Lile JD, Bektesh S, Collins F. GDNF: a glial cell line-derived neurotrophic factor for midbrain dopaminergic neurons. Science. 1993;260(5111):1130-2.

Lindahl M, Saarma M, Lindholm P. Unconventional neurotrophic factors CDNF and MANF: structure, physiological functions and therapeutic potential. Neurobiol Dis. 2017;97(Pt B):90-102.

Lindvall O, Brundin P, Widner $\mathrm{H}$, et al. Grafts of fetal dopamine neurons survive and improve motor function in Parkinson's disease. Science. 1990;247(4942):574-7.

Lovshin JA, Drucker DJ. Incretin-based therapies for type 2 diabetes mellitus. Nat Rev Endocrinol. 2009;5(5):262-9.

Lozano AM, Lipsman N. Probing and regulating dysfunctional circuits using deep brain stimulation. Neuron. 2013;77(3):406-24.

Madrazo I, Drucker-Colín R, Díaz V, Martínez-Mata J, Torres C, Becerril JJ. Open microsurgical autograft of adrenal medulla to the right caudate nucleus in two patients with intractable Parkinson's disease. N Engl J Med. 1987;316(14):831-4.

Magara A, Bühler R, Moser D, Kowalski M, Pourtehrani P, Jeanmonod D. First experience with MR-guided focused ultrasound in the treatment of Parkinson's disease. J Ther Ultrasound. 2014;2:11.

Maiti B, Perlmutter JS. A clinical trial of isradipine: what went wrong? Ann Intern Med. 2020;172(9):625-6. 
Markaki I, Winther K, Catrina SB, Svenningsson P. Repurposing GLP1 agonists for neurodegenerative diseases. Int Rev Neurobiol. 2020;155:91-112.

Marks WJ, Ostrem JL, Verhagen L, et al. Safety and tolerability of intraputaminal delivery of CERE-120 (adeno-associated virus serotype 2-neurturin) to patients with idiopathic Parkinson's disease: an open-label, phase I trial. Lancet Neurol. 2008;7(5):400-8.

Marras C, Beck JC, Bower JH, et al. Prevalence of Parkinson's disease across North America. NPJ Parkinsons Dis. 2018;4:21.

Martin-Bastida A, Ward RJ, Newbould R, et al. Brain iron chelation by deferiprone in a phase 2 randomised double-blinded placebo controlled clinical trial in Parkinson's disease. Sci Rep. 2017;7(1):1398.

Mazzulli JR, Xu YH, Sun Y, et al. Gaucher disease glucocerebrosidase and a-synuclein form a bidirectional pathogenic loop in synucleinopathies. Cell. 2011;146(1):37-52.

McCarty DM. Self-complementary AAV vectors; advances and applications. Mol Ther. 2008;16(10):1648-56.

McCormack AL, Mak SK, Henderson JM, Bumcrot D, Farrer MJ, Di Monte DA. Alpha-synuclein suppression by targeted small interfering RNA in the primate substantia nigra. PLoS One. 2010;5(8):e12122.

McKinnon C, Gros P, Lee DJ, et al. Deep brain stimulation: potential for neuroprotection. Ann Clin TransI Neurol. 2019;6(1):174-85.

McNeill A, Magalhaes J, Shen C, et al. Ambroxol improves lysosomal biochemistry in glucocerebrosidase mutation-linked Parkinson disease cells. Brain. 2014;137(Pt 5):1481-95.

Mendell JR, Al-Zaidy S, Shell R, et al. Single-Dose Gene-Replacement Therapy for Spinal Muscular Atrophy. N Engl J Med. 2017;377(18):1713-22.

Mendez I, Sanchez-Pernaute R, Cooper O, et al. Cell type analysis of functional fetal dopamine cell suspension transplants in the striatum and substantia nigra of patients with Parkinson's disease. Brain. 2005;128(Pt 7):1498-510.

Meng Y, Solomon B, Boutet A, et al. Magnetic resonance-guided focused ultrasound thalamotomy for treatment of essential tremor: A 2-year outcome study. Mov Disord. 2018;33(10):1647-50.

Merola A, Van Laar A, Lonser R, Bankiewicz K. Gene therapy for Parkinson's disease: contemporary practice and emerging concepts. Expert Rev Neurother. 2020;20(6):577-90.

Mishina M, Ishiwata K, Naganawa M, et al. Adenosine A(2A) receptors measured with [C]TMSX PET in the striata of Parkinson's disease patients. PLoS One. 2011;6(2):e17338.

Mittermeyer G, Christine CW, Rosenbluth KH, et al. Long-term evaluation of a phase 1 study of AADC gene therapy for Parkinson's disease. Hum Gene Ther. 2012;23(4):377-81.

Morabito G, Giannelli SG, Ordazzo G, et al. AAV-PHP.B-mediated globalscale expression in the mouse nervous system enables GBA1 gene therapy for wide protection from synucleinopathy. Mol Ther. 2017;25(12):2727-42.

Mori A. Mode of action of adenosine A2A receptor antagonists as symptomatic treatment for Parkinson's disease. Int Rev Neurobiol. 2014;119:87-116.

Mullin S, Smith L, Lee K, et al. Ambroxol for the treatment of patients with parkinson disease with and without glucocerebrosidase gene mutations: a nonrandomized, noncontrolled trial. JAMA Neurol. 2020;77(4):427-34.

Muramatsu S, Fujimoto K, Kato S, et al. A phase I study of aromatic L-amino acid decarboxylase gene therapy for Parkinson's disease. Mol Ther. 2010;18(9):1731-5.

Naldini L, Blömer U, Gage FH, Trono D, Verma IM. Efficient transfer, integration, and sustained long-term expression of the transgene in adult rat brains injected with a lentiviral vector. Proc Natl Acad Sci U S A. 1996;93(21):11382-8.

Naldini L, Blömer U, Gallay P, et al. In vivo gene delivery and stable transduction of nondividing cells by a lentiviral vector. Science. 1996;272(5259):263-7.

Niethammer M, Tang CC, LeWitt PA, et al. Long-term follow-up of a randomized AAV2-. JCl Insight. 2017;2(7):e90133.

Niethammer M, Tang CC, Vo A, et al. Gene therapy reduces Parkinson's disease symptoms by reorganizing functional brain connectivity. Sci Transl Med. 2018;10:469.

Oakley AE, Collingwood JF, Dobson J, et al. Individual dopaminergic neurons show raised iron levels in Parkinson disease. Neurology. 2007;68(21):1820-5.
Oakley AE, Collingwood JF, Dobson J, et al. Individual dopaminergic neurons show raised iron levels in Parkinson disease. Neurology. 2007:68(21):1820-5.

Olanow CW, Goetz CG, Kordower JH, et al. A double-blind controlled trial of bilateral fetal nigral transplantation in Parkinson's disease. Ann Neurol. 2003;54(3):403-14.

Olsen JC. Gene transfer vectors derived from equine infectious anemia virus. Gene Ther. 1998;5(11):1481-7.

Pagan FL, Hebron ML, Wilmarth B, et al. Nilotinib effects on safety, tolerability, and potential biomarkers in parkinson disease: a phase 2 randomized clinical trial. JAMA Neurol. 2020;77(3):309-17.

Pagano G, Niccolini F, Politis M. Imaging in Parkinson's disease. Clin Med (Lond). 2016;16(4):371-5.

Paisán-Ruíz C, Jain S, Evans EW, et al. Cloning of the gene containing mutations that cause PARK8-linked Parkinson's disease. Neuron. 2004;44(4):595-600.

Pal GD, Ouyang B, Serrano G, et al. Comparison of neuropathology in Parkinson's disease subjects with and without deep brain stimulation. Mov Disord. 2017;32(2):274-7.

Palfi S, Gurruchaga JM, Ralph GS, et al. Long-term safety and tolerability of ProSavin, a lentiviral vector-based gene therapy for Parkinson's disease: a dose escalation, open-label, phase 1/2 trial. Lancet. 2014;383(9923):1138-46.

Pardridge WM. Blood-brain barrier and delivery of protein and gene therapeutics to brain. Front Aging Neurosci. 2019;11:373.

Parmar M, Grealish S, Henchcliffe C. The future of stem cell therapies for Parkinson disease. Nat Rev Neurosci. 2020;21 (2):103-15.

Pascual A, Hidalgo-Figueroa M, Gómez-Díaz R, López-Barneo J. GDNF and protection of adult central catecholaminergic neurons. J Mol Endocrinol. 2011;46(3):R83-92.

Pasternak B, Svanström H, Nielsen NM, Fugger L, Melbye M, Hviid A. Use of calcium channel blockers and Parkinson's disease. Am J Epidemiol. 2012;175(7):627-35.

Paton DM. Istradefylline: adenosine A2A receptor antagonist to reduce "OFF" time in Parkinson's disease. Drugs Today (Barc). 2020;56(2):125-34.

Peschanski M, Defer G, N'Guyen JP, et al. Bilateral motor improvement and alteration of L-dopa effect in two patients with Parkinson's disease following intrastriatal transplantation of foetal ventral mesencephalon. Brain. 1994;117(Pt 3):(487-99.

Philippe S, Sarkis C, Barkats M, et al. Lentiviral vectors with a defective integrase allow efficient and sustained transgene expression in vitro and in vivo. Proc Natl Acad Sci U S A. 2006;103(47):17684-9.

Politis M. Neuroimaging in Parkinson disease: from research setting to clinical practice. Nat Rev Neurol. 2014;10(12):708-22.

Popat RA, Van Den Eeden SK, Tanner CM, et al. Coffee, ADORA2A, and CYP1A2: the caffeine connection in Parkinson's disease. Eur J Neurol. 2011;18(5):756-65.

Pringsheim T, Jette N, Frolkis A, Steeves TD. The prevalence of Parkinson's disease: a systematic review and meta-analysis. Mov Disord. 2014;29(13):1583-90.

Prothena Corporation P. (2020) Roche and Prothena will Advance Prasinezumab into Late-Stage Clinical Development Study in Parkinson's Disease. In: Book Roche and Prothena will Advance Prasinezumab into Late-Stage Clinical Development Study in Parkinson's Disease: GlobeNewswire. https://www.globenewswire.com/news-relea se/2020/10/20/2111378/0/en/Roche-and-Prothena-will-Advance-Prasi nezumab-into-Late-Stage-Clinical-Development-Study-in-Parkinson-sDisease.html. Accessed 19 Jan 2021.

Quartarone A, Cacciola A, Milardi D, et al. New insights into cortico-basalcerebellar connectome: clinical and physiological considerations. Brain. 2020;143(2):396-406.

Rascol O, Payoux P, Ory F, Ferreira JJ, Brefel-Courbon C, Montastruc JL. Limitations of current Parkinson's disease therapy. Ann Neurol. 2003;53(Suppl 3):S3-12.

Richardson RM, Kells AP, Rosenbluth KH, et al. Interventional MRI-guided putaminal delivery of AAV2-GDNF for a planned clinical trial in Parkinson's disease. Mol Ther. 2011;19(6):1048-57.

Ritz B, Rhodes SL, Qian L, Schernhammer E, Olsen JH, Friis S. L-type calcium channel blockers and Parkinson disease in Denmark. Ann Neurol. 2010;67(5):600-6. 
Rocha EM, Smith GA, Park E, et al. Glucocerebrosidase gene therapy prevents a-synucleinopathy of midbrain dopamine neurons. Neurobiol Dis. 2015;82:495-503.

Rodrigues RJ, Alfaro TM, Rebola N, Oliveira CR, Cunha RA. Co-localization and functional interaction between adenosine $\mathrm{A}(2 \mathrm{~A})$ and metabotropic group 5 receptors in glutamatergic nerve terminals of the rat striatum. $J$ Neurochem. 2005;92(3):433-41.

Rosario AM, Cruz PE, Ceballos-Diaz C, et al. Microglia-specific targeting by novel capsid-modified AAV6 vectors. Mol Ther Methods Clin Dev. 2016;3:16026.

Rossi S, Hallett M, Rossini PM, Pascual-Leone A, Group SoTC. Safety, ethical considerations, and application guidelines for the use of transcranial magnetic stimulation in clinical practice and research. Clin Neurophysiol. 2009;120(12):2008-39.

Ruppert MC, Greuel A, Tahmasian M, et al. Network degeneration in Parkinson's disease: multimodal imaging of nigro-striato-cortical dysfunction. Brain. 2020;143(3):944-59.

Sardi SP, Cheng SH, Shihabuddin LS. Gaucher-related synucleinopathies: the examination of sporadic neurodegeneration from a rare (disease) angle. Prog Neurobiol. 2015;125:47-62.

Sardi SP, Viel C, Clarke J, et al. Glucosylceramide synthase inhibition alleviates aberrations in synucleinopathy models. Proc Natl Acad Sci U S A. 2017;114(10):2699-704.

Sayin S, Cakmur R, Yener GG, Yaka E, Ugurel B, Uzunel F. Low-frequency repetitive transcranial magnetic stimulation for dyskinesia and motor performance in Parkinson's disease. J Clin Neurosci. 2014;21(8):1373-6.

Schindlbeck KA, Eidelberg D. Network imaging biomarkers: insights and clinical applications in Parkinson's disease. Lancet Neurol. 2018;17(7):629-40.

Schlogl H, Kabisch S, Horstmann A, et al. Exenatide-induced reduction in energy intake is associated with increase in hypothalamic connectivity. Diabetes Care. 2013;36(7):1933-40.

Schwab K, Frahm S, Horsley D, et al. A protein aggregation inhibitor, leucomethylthioninium bis(hydromethanesulfonate), decreases alpha-synuclein inclusions in a transgenic mouse model of synucleinopathy. Front Mol Neurosci. 2017;10:447.

Simuni T, Fiske B, Merchant K, Coffey CS, Klingner E, Caspell-Garcia C, Lafontant DE, Matthews H, Wyse RK, Brundin P, Simon DK. Randomized phase 2a study (NILO-PD). MedRxiv. 2020. https://doi. org/10.1101/2020.05.11.20093146(.

Shindou T, Mori A, Kase H, Ichimura M. Adenosine. A(2A) receptor enhances GABA(A)-mediated IPSCs in the rat globus pallidus. J Physiol. 2001;532(Pt 2):423-34

Shindou T, Nonaka H, Richardson PJ, Mori A, Kase H, Ichimura M. Presynaptic adenosine A2A receptors enhance GABAergic synaptic transmission via a cyclic AMP dependent mechanism in the rat globus pallidus. $\mathrm{Br} J$ Pharmacol. 2002;136(2):296-302

Shindou T, Richardson PJ, Mori A, Kase H, Ichimura M. Adenosine modulates the striatal GABAergic inputs to the globus pallidus via adenosine A2A receptors in rats. Neurosci Lett. 2003;352(3):167-70.

Simuni T, Fiske B, Merchant K, Coffey CS, Klingner E, Caspell-Garcia C, Lafontant DE, Matthews H, Wyse RK, Brundin P, Simon DK, Schwarzschild M, Weiner D, Adams J, Venuto C, Dawson TM, Baker L, Kostrzebski M, Ward T, Rafaloff G; Parkinson Study Group NILO-PD Investigators and Collaborators. Efficacy of Nilotinib in Patients With Moderately Advanced Parkinson Disease: A Randomized Clinical Trial. JAMA Neurol. 2020;e204725. https://doi.org/10.1001/jamaneurol.2020.4725.

Sinai A, Nassar M, Eran A, et al. Magnetic resonance-guided focused ultrasound thalamotomy for essential tremor: a 5-year single-center experience. J Neurosurg. 2019. https://doi.org/10.3171/2019.3.JNS19466.

Sinnige T, Yu A, Morimoto RI. Challenging proteostasis: role of the chaperone network to control aggregation-prone proteins in human disease. Adv Exp Med Biol. 2020;1243:53-68.

Sperling SA, Shah BB, Barrett MJ, et al. Focused ultrasound thalamotomy in Parkinson disease: Nonmotor outcomes and quality of life. Neurology. 2018;91(14):e1275-84.

Spieles-Engemann AL, Behbehani MM, Collier TJ, et al. Stimulation of the rat subthalamic nucleus is neuroprotective following significant nigral dopamine neuron loss. Neurobiol Dis. 2010;39(1):105-15.

Spieles-Engemann AL, Steece-Collier K, Behbehani MM, et al. Subthalamic nucleus stimulation increases brain derived neurotrophic factor in the nigrostriatal system and primary motor cortex. J Parkinsons Dis. 2011;1(1):123-36.

Spillantini MG, Schmidt ML, Lee VM, Trojanowski JQ, Jakes R, Goedert M. Alphasynuclein in Lewy bodies. Nature. 1997;388(6645):839-40.

Stocchi F, Rascol O, Hauser RA, et al. Randomized trial of preladenant, given as monotherapy, in patients with early Parkinson disease. Neurology. 2017:88(23):2198-206.

Sulzer D, Edwards RH. The physiological role of alpha-synuclein and its relationship to Parkinson's Disease. J Neurochem. 2019:150(5):475-86.

Takahashi K, Tanabe K, Ohnuki M, et al. Induction of pluripotent stem cells from adult human fibroblasts by defined factors. Cell. 2007;131(5):861-72.

Takahashi M, Suzuki M, Fukuoka M, et al. Normalization of overexpressed alpha-synuclein causing Parkinson's disease by a moderate gene silencing with RNA interference. Mol Ther Nucleic Acids. 2015;4:e241.

Tambasco N, Romoli M, Calabresi P. Levodopa in Parkinson's disease: current status and future developments. Curr Neuropharmacol. 2018;16(8):1239-52.

Tayebi N, Walker J, Stubblefield B, et al. Gaucher disease with parkinsonian manifestations: does glucocerebrosidase deficiency contribute to a vulnerability to parkinsonism? Mol Genet Metab. 2003;79(2):104-9.

Temel Y, Visser-Vandewalle V, Kaplan S, et al. Protection of nigral cell death by bilateral subthalamic nucleus stimulation. Brain Res. 2006;1120(1):100-5.

Therapeutics D. (2020) Denali Therapeutics announces broad pipeline progress including positive results from its LRRK2 program for Parkinson's disease. In: Book Denali therapeutics announces broad pipeline progress including positive results from its LRRK2 program for Parkinson's disease. https://www.denalitherapeutics.com/investors/press-relea se?id=7361. Accessed 19 Jan 2021.

Thompson V. Successful brain grafting science. 1890;16(392):78-9.

Thomson JA, Itskovitz-Eldor J, Shapiro SS, et al. Embryonic stem cell lines derived from human blastocysts. Science. 1998;282(5391):1145-7.

Tolosa E, Vila M, Klein C, Rascol O. LRRK2 in Parkinson disease: challenges of clinical trials. Nat Rev Neurol. 2020;16(2):97-107.

Tomac A, Lindqvist $E$, Lin LF, et al. Protection and repair of the nigrostriatal dopaminergic system by GDNF in vivo. Nature. 1995;373(6512):335-9.

Twelves D, Perkins KS, Counsell C. Systematic review of incidence studies of Parkinson's disease. Mov Disord. 2003;18(1):19-31.

Underwood CF, Parr-Brownlie LC. Primary motor cortex in Parkinson's disease: functional changes and opportunities for neurostimulation. Neurobiol Dis. 2020:147:105159.

Ungerstedt U. 6-Hydroxy-dopamine induced degeneration of central monoamine neurons. Eur J Pharmacol. 1968;5(1):107-10.

Ungerstedt U, Arbuthnott GW. Quantitative recording of rotational behavior in rats after 6-hydroxy-dopamine lesions of the nigrostriatal dopamine system. Brain Res. 1970;24(3):485-93.

Ungerstedt U, Ljungberg T, Steg G. Behavioral, physiological, and neurochemical changes after 6-hydroxydopamine-induced degeneration of the nigro-striatal dopamine neurons. Adv Neurol. 1974;5:421-6.

Valori CF, Ning K, Wyles M, et al. Systemic delivery of scAAV9 expressing SMN prolongs survival in a model of spinal muscular atrophy. Sci Transl Med. 2010;2(35):35ra42.

Vitek JL, Jain R, Chen L, et al. Subthalamic nucleus deep brain stimulation with a multiple independent constant current-controlled device in Parkinson's disease (INTREPID): a multicentre, double-blind, randomised, sham-controlled study. Lancet Neurol. 2020;19(6):491-501.

Volc D, Poewe W, Kutzelnigg A, et al. Safety and immunogenicity of the a-synuclein active immunotherapeutic PD01A in patients with Parkinson's disease: a randomised, single-blinded, phase 1 trial. Lancet Neurol. 2020;19(7):591-600.

Vuorimaa A, Rissanen E, Airas L. PET imaging of adenosine 2A receptors in neuroinflammatory and neurodegenerative disease. Contrast Media Mol Imaging. 2017:2017:6975841.

Wagle-Shukla A, Angel MJ, Zadikoff C, et al. Low-frequency repetitive transcranial magnetic stimulation for treatment of levodopa-induced dyskinesias. Neurology. 2007;68(9):704-5.

Wagner J, Ryazanov S, Leonov A, et al. Anle138b: a novel oligomer modulator for disease-modifying therapy of neurodegenerative diseases such as prion and Parkinson's disease. Acta Neuropathol. 2013;125(6):795-813. 
Wang Q, Akram H, Muthuraman M, et al. Normative vs. patient-specific brain connectivity in deep brain stimulation. Neuroimage. 2020;224:117307.

Ward RJ, Zucca FA, Duyn JH, Crichton RR, Zecca L. The role of iron in brain ageing and neurodegenerative disorders. Lancet Neurol. 2014;13(10):1045-60.

Warren Olanow C, Bartus RT, Baumann TL, et al. Gene delivery of neurturin to putamen and substantia nigra in Parkinson disease: a double-blind, randomized, controlled trial. Ann Neurol. 2015;78(2):248-57.

Wenning GK, Odin P, Morrish P, et al. Short- and long-term survival and function of unilateral intrastriatal dopaminergic grafts in Parkinson's disease. Ann Neurol. 1997;42(1):95-107.

West AB. Achieving neuroprotection with LRRK2 kinase inhibitors in Parkinson disease. Exp Neurol. 2017;298(Pt B):236-45

Whone A, Luz M, Boca M, et al. Randomized trial of intermittent intraputamenal glial cell line-derived neurotrophic factor in Parkinson's disease. Brain. 2019;142(3):512-25.

Whone AL, Boca M, Luz M, et al. Extended treatment with glial cell linederived neurotrophic factor in Parkinson's disease. J Parkinsons Dis. 2019;9(2):301-13.

Wong LF, Goodhead L, Prat C, Mitrophanous KA, Kingsman SM, Mazarakis ND. Lentivirus-mediated gene transfer to the central nervous system: therapeutic and research applications. Hum Gene Ther. 2006;17(1):1-9.

Wrasidlo W, Tsigelny IF, Price DL, et al. A de novo compound targeting alphasynuclein improves deficits in models of Parkinson's disease. Brain 2016;139(Pt 12):3217-36.

Wu Z, Asokan A, Samulski RJ. Adeno-associated virus serotypes: vector toolkit for human gene therapy. Mol Ther. 2006;14(3):316-27.

Xu Y, He Q, Wang M, et al. Safety and efficacy of magnetic resonance imagingguided focused ultrasound neurosurgery for Parkinson's disease: a systematic review. Neurosurg Rev. 2019. https://doi.org/10.1007/s1014 3-019-01216-y.

Yang A, Palmer AA, de Wit H. Genetics of caffeine consumption and responses to caffeine. Psychopharmacology. 2010;211(3):245-57.
Yang C, Guo Z, Peng H, et al. Repetitive transcranial magnetic stimulation therapy for motor recovery in Parkinson's disease: a Meta-analysis. Brain Behav. 2018;8(11):e01132.

Yokoe M, Mano T, Maruo T, et al. The optimal stimulation site for highfrequency repetitive transcranial magnetic stimulation in Parkinson's disease: a double-blind crossover pilot study. J Clin Neurosci. 2018;47:72-8.

Yoshii A, Constantine-Paton M. Postsynaptic BDNF-TrkB signaling in synapse maturation, plasticity, and disease. Dev Neurobiol. 2010;70(5):304-22.

Zaaroor M, Sinai A, Goldsher D, Eran A, Nassar M, Schlesinger I. Magnetic resonance-guided focused ultrasound thalamotomy for tremor: a report of 30 Parkinson's disease and essential tremor cases. J Neurosurg 2018:128(1):202-10.

Zhao HT, John N, Delic V, et al. LRRK2 antisense oligonucleotides ameliorate a-synuclein inclusion formation in a parkinson's disease mouse model. Mol Ther Nucleic Acids. 2017;8:508-19.

Zheng J, Zhang X, Zhen X. Development of adenosine A. ACS Chem Neurosci. 2019;10(2):783-91.

Zimprich A, Biskup S, Leitner P, et al. Mutations in LRRK2 cause autosomaldominant parkinsonism with pleomorphic pathology. Neuron. 2004;44(4):601-7.

Zufferey R, Dull T, Mandel RJ, et al. Self-inactivating lentivirus vector for safe and efficient in vivo gene delivery. J Virol. 1998;72(12):9873-80.

Zufferey R, Nagy D, Mandel RJ, Naldini L, Trono D. Multiply attenuated lentiviral vector achieves efficient gene delivery in vivo. Nat Biotechnol. 1997;15(9):871-5.

\section{Publisher's note}

Springer Nature remains neutral with regard to jurisdictional claims in published maps and institutional affiliations.
Ready to submit your research? Choose BMC and benefit from:

- fast, convenient online submission

- thorough peer review by experienced researchers in your field

- rapid publication on acceptance

- support for research data, including large and complex data types

- gold Open Access which fosters wider collaboration and increased citations

- maximum visibility for your research: over $100 \mathrm{M}$ website views per year

At $\mathrm{BMC}$, research is always in progress.

Learn more biomedcentral.com/submissions 